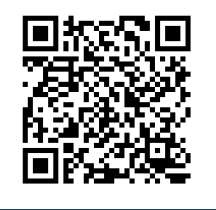

Keywords:

Eucalyptus

Seeds morphology trait

Salt stress

Osmotic potentials

Principal component analysis

Modeling

Historic

Received 27/03/2019

Accepted 22/05/2019

Correspondence:

jaouadiwahbi@gmail.com

DOl:

10.1590/01047760201925022635
Kaouther Mechergui', Wahbi Jaouadi',2+, Souheila Naghmouchi', Moodi Alsubeie ${ }^{4}$, Mohamed Larbi Khouja ${ }^{\text {la }}$

\section{MICROMORPHOLOGICAL OBSERVATION OF EUCALYPTUS SEEDS, MULTIVARIATE STATISTICAL ANALYSES AND MODELING OF THEIR GERMINATION UNDER SALT STRESS AND OSMOTIC CONSTRAINT}

MECHERGUI, K.; JAOUADI,W.; NAGHMOUCHI S.; ALSUBEIE, M.; KHOUJA, M. L. Micromorphological observation of Eucalyptus seeds, multivariate statistical analyses and modeling of their germination under salt stress and osmotic constraint. CERNE, v. 25, n. 2, p.I56-I7I, 2019.

\section{HIGHLIGHTS}

Eucalyptus is a very important reforestation species in Tunisia, it is from North to South of the country.

Micromorphological characters provide basis for classification and delimitation of genus Eucalyptus.

Micromorphological features study of seeds of 19 species of eucalyptus reforested in Tunisia facilitated the identification of these species.

The hybrid $E$. gomphocephala $\times E$. cornuta was more tolerant to salt stress and osmotic potential than the others Eucalyptus species studied.

\section{ABSTRACT}

Micromorphological characters including surface, length and width of seeds were recorded for 19 species of Eucalyptus (Myrtaceae) using stereomicroscope to determine the importance of seed morphological characters as an additional tool for identification. With the aim of selecting and valorizing abiotic-stress-tolerant species with landscape and industrial values and would be a potential solution for valorizing dry arid area and development of land degradation, we launched the assessment of the performance of five Eucalyptus species ( $E$. torquata, $E$. sargenti, E. gillii, E. gomphocephala $x$ E. cornuta and $E$. microtheca) under salinity and osmotic potential constraints. Several $\mathrm{NaCl}$ concentrations $\left(0,3,6,9,12\right.$, and $\left.15 \mathrm{~g} \cdot \mathrm{L}^{-1}\right)$ and several osmotic potentials $(0,-0.03,-0.1,-0.7,-1$ and $-1.6 \mathrm{MPa})$ were applied to seeds cultivated in petri dishes for a period of one month. Germination rates, means time of germination and coefficent of velocity were evaluated to better understand the salt stress and osmotic potential effect on germination. Univariate and multivariate analyses were used to identify the major characteristics pertaining to salinity tolerance. Modeling of germination under both constraints saline and osmotic stress is carried out to predict the behavior of the species. The hybrid E. gomphocephala $\times$ E. cornuta was more tolerant to salt stress ( $15 \%$ at $12 \mathrm{~g} \cdot \mathrm{L}^{-1}$ ) and osmotic potential $(6 \mathrm{I} \%$ at $-\mathrm{I} .6 \mathrm{MPa}$ ) than the others species of Eucalyptus; it showed a higher germination percentage under all tested potentials, when compared to the not hybrid species of Eucalyptus. Our analyses of seeds morphology revealed that the observations shown diversity of morphological characters in seeds. Area, length and width of seeds vary significantly between species of Eucalyptus. Micromorphological characters can provide basis for classification and delimitation of genus Eucalyptus.

' National Research Institute for Rural Engineering, Water, and Forestry (INRGREF). Hédi Karrai Street, P.O. Box I0, 2080, Ariana, Carthage University. Tunisia ORCID: 0000-0002-285I-8026a

${ }^{2}$ Silvo-Pastoral Institute of Tabarka. Tabarka 8I I 0. Jendouba University. Tunisia

${ }^{3}$ Princess Norah Bint Abdurrahman University, College of Sciences, Biology department, Kingdom of Saudi Arabia;

${ }^{4}$ Imam Muhammed bin Saud Islamic University, College of Sciences, Biology department, Kingdom of Saudi Arabia. 


\section{INTRODUCTION}

The genus Eucalyptus is a member of the Myrtaceae family. There are more than 700 species of Eucalyptus, mostly originating from the Australian continent, with a very small number found on the neighboring islands of Papua New Guinea, Indonesia, and Philippines (Yang et al., 2016). The total plantation area of Eucalyptus covers more than 19 million ha, and representing one of the most common plantation forest species in the world (Wen, 2008). China ranks second in the world in the plantation area of Eucalyptus, with a plantation area of more than 4.5 million ha in southern China ( $\mathrm{Li}, 20 \mathrm{I} 5)$.

Currently, the plantation area of Eucalyptus forests in Hainan (China) is nearly 200.000 ha, covering 18 cities and counties throughout the island (Yang et al., 2016). Eucalyptus name originates from the Greek word «Eucalyptol» which means "well covered» (Ishag et al., 2018). Leaf extracts of Eucalyptus have been approved as food additives (Gilles et al., 20 I0). Because of their rapid growth rates (Cossalter and Pye-Smith, 2003), wide adaptability (Johansson and Tuomela, 1996; Gardner, 2007) and high productivity (Singh and Toky, 1995), Eucalyptus plantations generate large economic returns.

Nevertheless, there is continuing controversy about their ecological functions (Zhang and Fu, 2009). Eucalyptus occupies one of the largest planted areas in Brazil and presents high productive and technological potential, and its wood is used in the pulp and paper industry, for the production of fiber panels and agglomerates, in the manufacture of furniture, as well as in firewood and in sawmills (IBÁ, 2015; Lopes et al., 201 I; Soares et al., 2003; Souza et al., 2004). Eucalyptus spp. are indigenous to Australia; they have been widely introduced into countries throughout the world because of their rising demand for paper and plywood (Turnbull, 1999; Cossalter and Pye-Smith, 2003). It is used in the fabrication of pulp and paper, in sawn lumber for structural purposes, engineering wood products, and flors (Rezende et al., 2018). Eucalyptus monoculture provides distinct products, such as wood, charcoal, resins, plywood, cellulosic ethanol, cellulose and paper (Takahashi et al., 2004). Eucalyptus species might be exploited as natural antibiotic for the treatment of several infectious diseases (Ishag et al., 2018).

Eucalyptus have been successfully introduced worldwide; it is used for ornementation, afforestation, or to obtain timber, gum, pulp and paper and it's also known by its cosmetic and medicinal values. Essential oil is used in food, perfumery, beverage and pharmaceutical industry
(Batish et al., 2008; Leicach et al., 2012; Vecchio et al., 2016). In Tunisia, the total area planted with Eucalyptus is about 29000 ha (Oueslati, 2005). In 1957, total II7 Eucalyptus have been introduced in Tunisia. They were used essentially as fire wood, for the production of mine wood and against the erosion (Khouja et al., 200I). Eucalyptus camaldulensis and Eucalyptus gomphocephala account for more than $80 \%$ of the Eucalyptus stand.

The governorate of Bizerte in Tunisia owns 10806 ha, $37 \%$ of the total area, the majority being located in the region of Sejenane in Bizerte (Oueslati, 2005). In Tunisian folk medicine, inhalation of Eucalyptus sp.'s essential oil has been traditionally used to treat respiratory tract disorders such as pharyngitis, bronchitis and sinusitis (Boukef, 1986). Many studies have been demonstrated their antibacterial, antifungal and antiviral activities of Eucalyptus sp.'s essential oil against a wide range of microorganisms (Elaissey findi et al., 2015 ; Su et al., 2006; Cermelli et al., 2008; Gilles et al., 2010; Jha et al., 20l4). Few investigations were reported on the biological activities of Eucalyptus oils worldwide (Elaissi et al., 20I2). Antitryptical, anticoagulant and hemagglutinating activities of Eucalyptus sp. seeds were identified (Queiroz dos Santos et al., 2019). Seed germination is used to calculate sowing rate, evaluate the physiological quality of a lot, and establish criteria for commercialization (Martins et al., 2008; Tomaz et al., 2016).

Nevertheless, the increase of the soil salinisation is a consequence of the irrigated cultivations, resulting in salt accumulations that are harmful for the plants (Lopes da Silva et al., 20I2) leading to a reduced productivity and lost of agricultural practices. Effects of salt stress on various Eucalyptus species have been reported in (Woodward and Bennett, 2005; Merchant et al., 2007; Nasim et al., 2008; Zohar et al., 20 I0; Silva et al., 20I2; Feikema et al., 20I2; Cha-um et al., 20I3) . It is supposed that Eucalyptus species could be one of the bio-economic plants suitable to grow in salt affected soils and arid climatic conditions (Nasim et al., 2008; Zohar et al., 2010; Feikema et al., 2012; Silva et al., 2012; Cha-um et al., 2013).

According to the latest forest inventory in Tunisia (INF, 20I0), the area of Eucalyptus in was estimated at 4I 397 ha almost $3.63 \%$ of the total area of the Tunisian forest. Given the importance of this species, this area should be protected and valued for the multiple use of this species. Indeed, soils affected by salinity in Tunisia cover about $1.5 \times 10^{6}$ ha, representing $10 \%$ of the area of the country (Hachicha, 2007). The alternative 
approach is using plants that display salt tolerance and adaptation behavior, and its yields remain satisfactory versus high levels of salt (Ayadi et al., 218). However, little is known about seed germination of these five species of Eucalyptus under these harsh environmental conditions. The objective of this experiment was to study the micromorphological features i.e. seed length, width and area, for 19 species of Eucalyptus in Tunisia to facilitate the identification of these species and evaluate the effect of salt stress and osmotic pressure on five Eucalyptus species: Eucalyptus torquata, Eucalyptus sargenti, Eucalyptus gillii, Eucalyptus gomphocephala $\mathrm{x}$ Eucalyptus cornuta and Eucalyptus microtheca in order to understand the adaptation of Eucalyptus species to the different abiotic constraints and to develop a salinity and drought tolerance classification, which are important criteria for forest managers, nurseries and foresters in the choice of species for seedling production, landscape enhancement or reforestation program in order to plan, in a further attempt, its introduction for forest and urban forest cultivation.

\section{MATERIAL AND METHODS}

This work was carried out in the Forest Ecology Laboratory and Laboratory of Management and Valorization of Forest Resources from the National Research Institute of Rural Engineering, Water and Forests in Tunisia.

\section{Plant material}

All seeds used in this study were collected from the Eucalyptus population in Rtiba Arboretum (seed orchard) in Nabeul Gouvernorate in north of Tunisia, it occupies an area of about 100 ha at an altitude of $450 \mathrm{~m}$. Five Eucalyptus species seeds were collected for germination under salt stress and osmotic potential constraints: $E$. torquata, E. sargenti, E. gillii, E. gomphocephala $\times E$. cornuta and $E$. microtheca. Nineteen Eucalyptus species were collected for seed morphometric measurements: $E$. sargenti, E. saligna, $E$. cornuta, E. gomphocephala, E. accedens, E. leucoxylon, E. microtheca, E. Stoatei, E. platypus, E. perriniana, E. lehmannii, $E$. viminalis, $E$. gillii, $E$. diversifolia, $E$. torquata, $E$. dumosa, $E$. angulosa, E. burracoppinensis and E. pimpiniana.

\section{Seed morphometric measurements}

We collected 20 capsules from 10 randomly selected individuals of nineteen Eucalyptus species and allowed them to ripen in the laboratory for 10 days, exposed to the air. Only 20 fruits were collected from the capsules of every species and was harvested. Seeds were subsequently manually extracted from dried fruits. After extraction, 20 seeds were randomly selected and the length, width, and area were individually measured to the nearest $0.01 \mathrm{~mm}$ using strero-microscope (leica DM 205-C) in the Laboratory of Management and Valorization of Forest Resources.

Germination procedure of five Eucalyptus species under salt stress and osmotic potential constraints

Collected seeds offive Eucalyptus species were processed in an air blower, stored in plastic containers and placed in a cool chamber until use. Seeds were placed in Petri dishes on perlite containing a polyethylene glycol solution (PEG 6000) to germinate under osmotic potentials of $0,-0.03,-0.1,-0.7,-\mathrm{I}$ and $-\mathrm{I} .6 \mathrm{MPa}$ and kept in incubator at $25^{\circ} \mathrm{C}$. Seeds were placed to germinate under $\mathrm{NaCl}$ induced salt stress, at 0.0 (control sample), $3,6,9,15$ and $I 5 \mathrm{~g}$ of salt/L.

Germination was evaluated daily for 30 days, in order to determine germination rate (\%) mean time of germination (days) and germination velocity index ( $\mathrm{VI})$. For each type of stress, the experiment was conducted in completely randomized design, using five replications of 20 seeds comprising 6 concentrations of $\mathrm{NaCl}$ salt and 6 concentrations of osmotic potential. Seeds were considered to be germinated when the root length reached the seed length and shoot length reached half of the seed length (Cheng et al., 2014 ; Wang et al., 2014). The number of germinated seed was counted every day for 30 days. The standard germination test ended at 30 days because from this date on, no normal seedlings emerged in any treatment for three successive counts (Affonso et al., 20I8)

The parameters of the germination rate (GR), the meantimeofgermination(MTG)andthecoeffientofvelocity (CV) of Kotowski (1962), were calculated as follows, Here, $n$ is the total number of germinated seeds and $N$ is the total number of tested seeds. Where $D$ is the number of days counted from the date of sowing and $N$ is the number of seeds germinated on day $D$. Coeffient of velocity: equation I, where, $n i$ is the number of seeds newly germinating on day $i$ and $D i$ is the number of days from sowing

$$
\begin{aligned}
& \operatorname{GR}(\%)=\mathrm{n} / \mathrm{N} \cdot 100 \\
& \mathrm{MGT}=\sum \mathrm{DN} / \sum \mathrm{N} \\
& \mathrm{CV}=\sum(\mathrm{ni} \times \mathrm{Di}) / \sum \mathrm{ni}
\end{aligned}
$$




\section{Statistical analysis}

The data of the diffrent parameter values were subjected to one-way ANOVA with SPSS 17.0 (SPSS Inc., Chicago, IL, USA). The differences between the means were tested with the Tukey test and values of $P \leq 0.05$ were considered significantly different (Sokal and Rohlf, 1995). Principal component analysis (PCA) of germination parameters data was performed with the $R$ language. An absolute value of 0.50 was used in the loading matrices to select the characteristics in a particular principal component (PC). Correlations between variables were calculated with Spearman correlation coefficients. Multiple linear regression (MLR) analyses based on least-square procedures are usually used for estimating the variable effects involved in a model. The success of MLR can be measured by evaluating the magnitude of the adjusted $R^{2}$, the residual standard error (RSE) for the regression, and the results of the Student $t$-test for the individual predictor variables.

\section{RESULTS}

Seed morphometric measurements of nineteen Eucalyptus species

Morphological traits of seeds of nineteen species of Eucalyptus were observed under stereo microscope (Figure I). Area, length and width of seeds varied significantly between the different species (Table I). This indicates that in the same family of Myrtaceae and in the same genus and species, the morphological characteristics of the seeds vary significantly. Seed morphometric measurements of nineteen Eucalyptus species were represented in Table 2. Eucalyptus seeds had a length between $1.35 \pm 0.15 \mathrm{~mm}$ and $2.70 \pm$ $0.4 \mathrm{Imm}$, width between $1.09 \pm 0.1 \mathrm{I} \mathrm{mm}$ and $\mathrm{I} .84 \pm 0.29$ $\mathrm{mm}$, and area seeds between $1.32 \pm 0.32 \mathrm{~mm}^{2}$ and 3.65 $\pm 0.66 \mathrm{~mm}^{2}$. E. angulosa had the greatest area of seed and E. dumosa had the highest length of seed. Length and width of seeds were positively correlated $(P<0.001$; Pearson coefficient $=0.685$ ) and in the simple linear regression $(y=a x+b) R^{2}=0.469$ and $A C_{c}=27,866$, as well length and area of seeds were positively correlated $(P<0.00$ I; Pearson coefficient $=0.914 ; R^{2}=0.836 ; A I C c=63.206$ ) also that width and area of seeds were positively correlated $\left(\mathrm{P}<0.001\right.$; Pearson coefficient $=0.822 ; \quad \mathrm{R}^{2}=0.675$; $A I C c=121,45)$. The interactions between morphological seed traits were tested by multivariate analysis, PCA. The first two components (FI and F2) explained $97 \%$ of the total variation. The first component (axis I) explained $99.60 \%$ of the variation, followed by $1.15 \%$ for the second component

TABLE I Analysis of variance of seeds parameters of 19 species of Eucalyptus.

\begin{tabular}{cccccc}
\hline Parameters of seeds & Df & Sum & Sq & F value & $\operatorname{Pr}(>\mathrm{F})$ \\
\hline Area of seeds & I8 & 276.71 & 15.373 & 65.02 & $<2 \mathrm{e}-16^{* * * *}$ \\
Lengh of seeds & 18 & 72.39 & 4.022 & 50.74 & $<2 \mathrm{e}-16^{* * * *}$ \\
Widh of seeds & I8 & 26.30 & 1.4612 & 28.34 & $<2 \mathrm{e}-16^{* * * *}$ \\
\hline
\end{tabular}

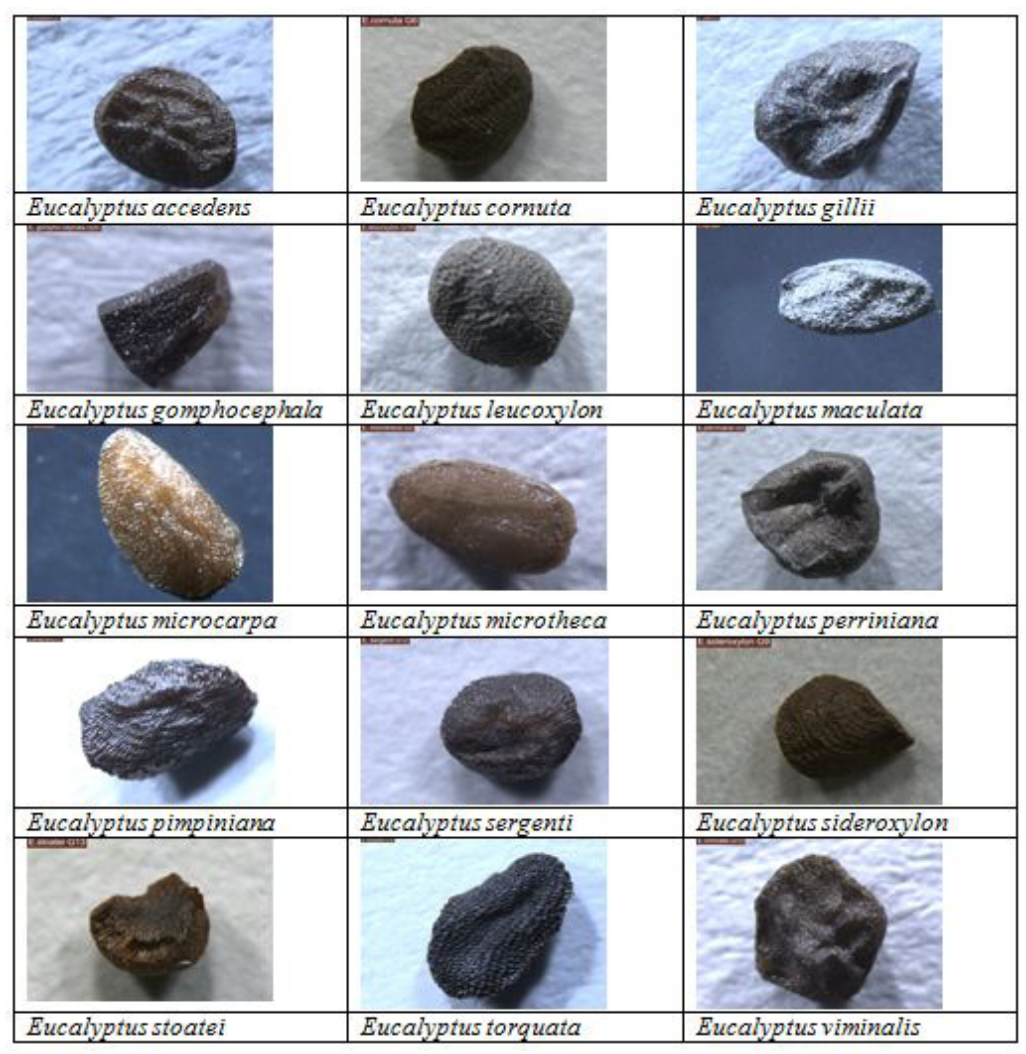

FIGURE I Seeds of Eucalyptus species observed under stereomicroscope. 
TABLE 2 Descriptive statistique of morphometric seeds parameters of 19 species of Eucalyptus.

\begin{tabular}{cccccccccc}
\hline & \multicolumn{3}{c}{$\begin{array}{c}\text { Area of seeds } \\
\left(\mathrm{mm}^{2}\right)\end{array}$} & \multicolumn{3}{c}{$\begin{array}{c}\text { Lengh of seeds } \\
(\mathrm{mm})\end{array}$} & \multicolumn{3}{c}{$\begin{array}{c}\text { Widh of seeds } \\
(\mathrm{mm})\end{array}$} \\
\hline & mean & $\mathrm{SD}$ & $\mathrm{CV}$ & mean & $\mathrm{SD}$ & $\mathrm{CV}$ & mean & $\mathrm{SD}$ & $\mathrm{CV}$ \\
\hline E. accedens & 1.42 & 0.25 & 0.17 & 1.50 & 0.19 & 0.12 & 1.20 & 0.12 & 0.10 \\
E. angulosa & 3.65 & 0.66 & 0.18 & 2.69 & 0.34 & 0.12 & 1.84 & 0.29 & 0.15 \\
E. burracoppinensis & 3.40 & 0.37 & 0.11 & 2.58 & 0.31 & 0.11 & 1.82 & 0.22 & 0.12 \\
E. cornuta & 1.53 & 0.19 & 0.12 & 1.46 & 0.20 & 0.14 & 1.14 & 0.26 & 0.22 \\
E. diversifolia & 3.01 & 0.46 & 0.15 & 2.22 & 0.22 & 0.09 & 1.74 & 0.28 & 0.16 \\
E. dumosa & 3.52 & 0.52 & 0.14 & 2.70 & 0.41 & 0.15 & 1.82 & 0.22 & 0.12 \\
E. gillii & 2.25 & 0.35 & 0.15 & 2.01 & 0.26 & 0.13 & 1.49 & 0.15 & 0.10 \\
E. gomphocephala & 1.45 & 0.72 & 0.50 & 1.55 & 0.41 & 0.26 & 1.24 & 0.28 & 0.23 \\
E. lehmannii & 2.17 & 0.43 & 0.19 & 1.92 & 0.23 & 0.11 & 1.48 & 0.18 & 0.12 \\
E. leucoxylon & 1.49 & 0.41 & 0.27 & 1.50 & 0.23 & 0.15 & 1.19 & 0.18 & 0.15 \\
E. microtheca & 1.71 & 0.28 & 0.16 & 1.88 & 0.20 & 0.11 & 1.27 & 0.23 & 0.18 \\
E. perriniana & 2.30 & 0.51 & 0.22 & 2.02 & 0.19 & 0.09 & 1.56 & 0.27 & 0.17 \\
E. pimpiniana & 3.16 & 0.57 & 0.15 & 2.55 & 0.26 & 0.10 & 1.82 & 0.30 & 0.16 \\
E. platypus & 1.62 & 0.16 & 0.10 & 1.63 & 0.13 & 0.08 & 1.33 & 0.17 & 0.13 \\
E. saligna & 1.32 & 0.32 & 0.24 & 1.61 & 0.27 & 0.17 & 1.09 & 0.11 & 0.10 \\
E. sargenti & 1.17 & 0.14 & 0.12 & 1.35 & 0.15 & 0.11 & 1.13 & 0.11 & 0.09 \\
E. stoatei & 1.51 & 0.28 & 0.18 & 1.61 & 0.24 & 0.15 & 1.31 & 0.20 & 0.15 \\
E. torquata & 3.16 & 0.68 & 0.21 & 2.36 & 0.35 & 0.15 & 1.74 & 0.21 & 0.12 \\
E. viminalis & 2.31 & 0.95 & 0.41 & 2.02 & 0.42 & 0.21 & 1.47 & 0.28 & 0.19 \\
\hline
\end{tabular}

(axis 2) (Figure 2). Width, length and area seeds were strongly correlated (Figure 2). Principal component analysis (Figure 2 and 3) showed three groups of Eucalyptus seeds: Group I consists of: E. sargenti, E. saligna, E. cornuta, E. gomphocephala, E. accedens, $E$. leucoxylon, $E$. microtheca, $E$. stoatei and $E$. platypus. Group 2 consists of $E$. perriniana, $E$. lehmannii, E. viminalis and E. gillii. Group 3 consists of
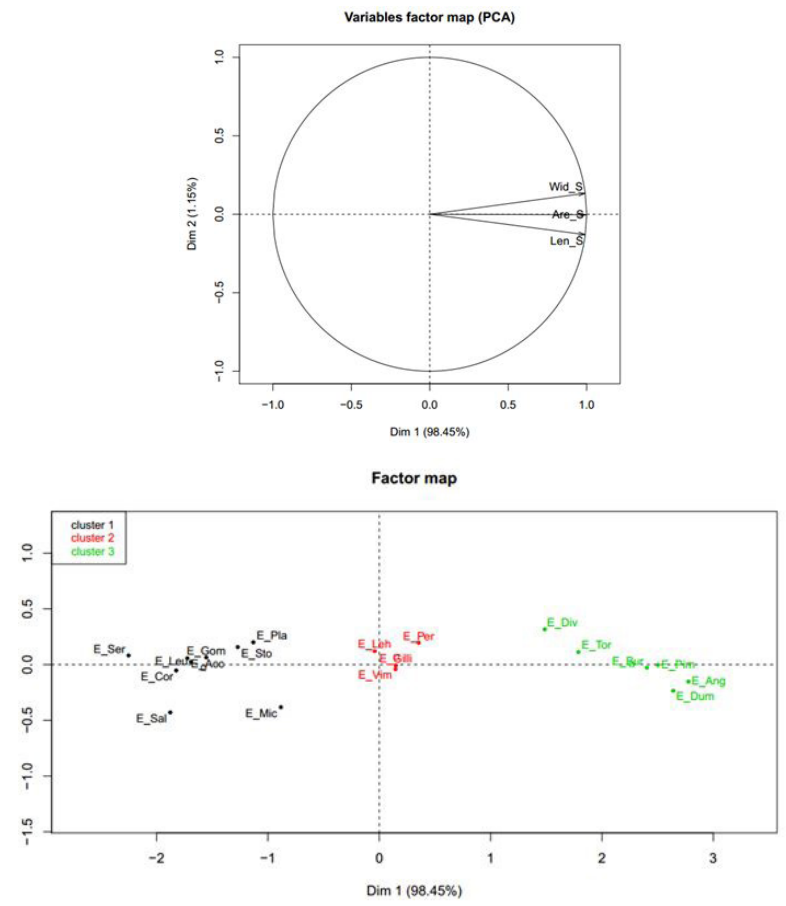

FIGURE 2 Principal component analysis, circle of correlation of seeds morphological traits of 19 Eucalyptus species in the factorial plane FI $\times$ F2 (Wid_S : widh of seeds ;Are $S$ : area of seeds ; Len $S$ : lenght of seeds) /19 Eucalyptus species : E. accedens : E. angulosa : $E$. burracoppinensis : E. cornuta : E. diversifolia : $E$. dumosa : E. gillii : E. gomphocephala : E. lehmannii : E. leucoxylon : E. microtheca : E. perriniana : E. pimpiniana : E. platypus : E. saligna : E. sargenti : E. stoatei : E. torquata : E. viminalis.
E. diversifolia, E. torquata, E. dumosa, E. angulosa, E. burracoppinensis and E. pimpiniana.

Effect of salt stress on germination of five Eucalyptus species

The results for the germination behavior of the five Eucalyptus seeds in terms of germination rate under the effect of different $\mathrm{NaCl}$ concentrations are shown in Table 3. Interestingly, germination was affected by salinity and seeds were not able to germinate at up to 9, 12 and $15 \mathrm{~g} \cdot \mathrm{L}^{-1} \mathrm{NaCl}$. At $12 \mathrm{~g} \cdot \mathrm{L}^{-1}$ the rates varied between $4 \%$ for Eucalyptus microtheca and 15\% for Eucalyptus gomphocephala, respectively. This indicates that the five Eucalyptus species had lower germination rate even in high salt stress. According to the statistical analysis, there was a significant difference between the control and the plants subjected to 12 and $15 \mathrm{~g} \cdot \mathrm{L}^{-1} \mathrm{NaCl}$ treatments, that their germination rate did not reach $16 \%$. Salinity reduced the rate of Eucalyptus germination, the latter dropped to 0 for Eucalyptus gillii, 3\% for Eucalyptus microtheca and Eucalyptus gomphocephala when treatment reached $15 \mathrm{~g} \cdot \mathrm{L}^{-1} \mathrm{NaCl}$. The results of the analysis of variance confimed that the salinity levels influenced the percentage of germination, the mean germination time and velocity index. Mean germination rate comparison did not reveal

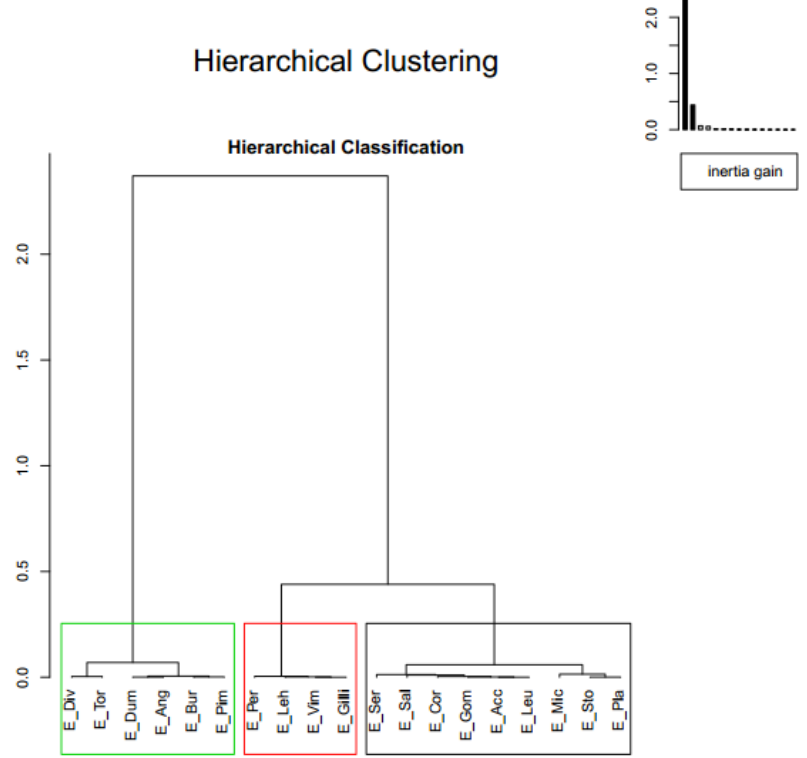

FIGURE 3 Hierarchical classifiation of morphological traits of seeds of 19 Eucalyptys speccies (E_Acc : E. accedens / E_Ang : E. angulosa / E_Bur : E. burracoppinensis / E_Cor :E. cornuta / E_Div : E. diversifolia / E_Dum : E. dumosa / E_Gilli :E. gillii / E_Gom :E. gomphocephala / E_Leh :E. lehmannii / E_Leu : E. leucoxylon / E_Mic : E. microtheca /E_Per : E. perriniana / E_Pim : E. pimpiniana / E_Pla : E. platypus / E_Sal : E. saligna / E_Ser : E. sargenti / E_Sto : $E$. stoatei / E_Tor : E. torquata / E_Vim :E. viminalis) 
TABLE 3 Analysis of variance and multiple comparison of means of germination rate, means time of germination and velocity index of seeds of five Eucalyptus species after transfer from $0,3,6,9,12$, and $15 \mathrm{~g} \cdot \mathrm{l}^{-1} \mathrm{NaCl}$ at $25^{\circ} \mathrm{C}$. Data are means $\pm \mathrm{SD}$. Different letters indicate signifiant diffrences between treatments $(\mathrm{NaCl})$ at $\mathrm{P}<0.05$ according to the Tukey test.

\begin{tabular}{|c|c|c|c|c|c|c|c|c|}
\hline Species & Parameters & $0{\mathrm{~g} \cdot \mathrm{I}^{-1}}^{-1}$ & $3 g \cdot 1^{-1}$ & $6 \mathrm{~g} \cdot \mathrm{l}^{-1}$ & $9 g \cdot 1^{-1}$ & $12 \mathrm{~g} \cdot \mathrm{I}^{-1}$ & $15 \mathrm{~g} \cdot \mathrm{I}^{-1}$ & $\operatorname{Pr}(>\mathrm{F})$ \\
\hline \multirow{3}{*}{$\begin{array}{l}\text { Eucalyptus } \\
\text { Sargenti }\end{array}$} & $\begin{array}{c}\text { Germination rate } \\
(\%)\end{array}$ & $93 \pm 8.36 b$ & $69 \pm 27.70 b$ & $20 \pm 17.32 a$ & $12 \pm 9.08 \mathrm{a}$ & $6 \pm 4.18 a$ & $\mathrm{I} \pm 2.23 \mathrm{a}$ & $0.000 * * *$ \\
\hline & $\begin{array}{l}\text { Means time of } \\
\text { germination } \\
\text { (Days) }\end{array}$ & $6.52 \pm 0.77 a b$ & $8.45 \pm 1.69 a b$ & $15.44 \pm 2.15 b$ & $13.46 \pm 9.13 \mathrm{ab}$ & $13.80 \pm 7.88 \mathrm{ab}$ & $3.40 \pm 7.60 \mathrm{a}$ & $0.0227^{*}$ \\
\hline & Velocity index & $15.52 \pm 2.09 c$ & $12.24 \pm 2.57 \mathrm{c}$ & $6.59 \pm 1.06 b$ & $5.19 \pm 3.43 \mathrm{ab}$ & $4.67 \pm 2.66 \mathrm{ab}$ & $1.17 \pm 2.62 \mathrm{a}$ & $0.000 * * *$ \\
\hline \multirow{3}{*}{$\begin{array}{c}\text { Eycalyptus } \\
\text { Gompho-cornuta }\end{array}$} & $\begin{array}{c}\text { Germination rate } \\
(\%)\end{array}$ & $99 \pm 5.47 d$ & $73 \pm 9.74 c d$ & $49 \pm 33.42 b c$ & $16 \pm 12.94 \mathrm{ab}$ & $15 \pm 28.06 \mathrm{ab}$ & $3 \pm 4.47 a$ & $0.000 * * *$ \\
\hline & $\begin{array}{c}\text { Means time of } \\
\text { germination } \\
\text { (Days) }\end{array}$ & $6.47 \pm 2.38 \mathrm{a}$ & $6.72 \pm 1.11 \mathrm{a}$ & $10.85 \pm 3.78 a$ & $8.45 \pm 3.37 a$ & $5.44 \pm 5.6 \mathrm{la}$ & $6.50 \pm 8.90 a$ & 0.390 \\
\hline & Velocity index & $16.79 \pm 4.65 b$ & $15.14 \pm 2.08 \mathrm{~b}$ & $10.33 \pm 4.12 \mathrm{ab}$ & $8.61 \pm 6.54 a b$ & $7.63 \pm 8.29 \mathrm{ab}$ & $2.46 \pm 3.37 \mathrm{a}$ & $0.003 * *$ \\
\hline \multirow{3}{*}{$\begin{array}{l}\text { Eycalyptus } \\
\text { Microtheca }\end{array}$} & $\begin{array}{c}\text { Germination rate } \\
(\%)\end{array}$ & $93 \pm 5.70 c$ & $4 I \pm 17.10 b$ & $29 \pm 16.73 b$ & $7 \pm 4.47 a$ & $4 \pm 6.5 \mathrm{la}$ & $3 \pm 6.70 a$ & $0.000 * * *$ \\
\hline & $\begin{array}{l}\text { Means time of } \\
\text { germination } \\
\text { (Days) }\end{array}$ & $13.30 \pm 3.96 a$ & $12.02 \pm 1.66 \mathrm{a}$ & $12.36 \pm 2.05 a$ & $13.10 \pm 7.87 a$ & $9.33 \pm 12.8 \mathrm{Ia}$ & $3.80 \pm 9.49 a$ & 0.320 \\
\hline & Velocity index & $8.02 \pm 2.40 \mathrm{~b}$ & $8.45 \pm 1.25 b$ & $8.29 \pm 1.54 b$ & $5.03 \pm 2.99 \mathrm{ab}$ & $1.72 \pm 2.36 \mathrm{a}$ & $1.05 \pm 2.35 \mathrm{a}$ & $0.000 * * *$ \\
\hline \multirow{3}{*}{ Eycalyptus Gillii } & $\begin{array}{c}\text { Germination rate } \\
(\%)\end{array}$ & $99 \pm 2.23 \mathrm{~d}$ & $43 \pm 12.54 c$ & $33 \pm 36.50 b c$ & $8 \pm 13 a b$ & $4 \pm 4.18 \mathrm{ab}$ & $0.00 \pm 000 a$ & $0.000 * * *$ \\
\hline & $\begin{array}{c}\text { Means time of } \\
\text { germination } \\
\text { (Days) }\end{array}$ & $7.76 \pm 1.4 \mathrm{Iab}$ & $\mid 5.21 \pm 4.27 b$ & $18.26 \pm 4.64 b$ & $8.36 \pm 11.60 \mathrm{ab}$ & $8.70 \pm 8.3 \mathrm{Iab}$ & $0.00 \pm 000 a$ & $0.002 * *$ \\
\hline & Velocity index & $13.17 \pm 2.07 d$ & $7.23 \pm 2.98 c$ & $5.75 \pm 1.36 b c$ & $1.97 \pm 2.69 \mathrm{ab}$ & $4.33 \pm 4.19 \mathrm{ac}$ & $0.00 \pm 000 \mathrm{a}$ & $0.000 * * *$ \\
\hline \multirow{3}{*}{$\begin{array}{c}\text { Eycalyptus } \\
\text { Torquata }\end{array}$} & $\begin{array}{c}\text { Germination rate } \\
(\%)\end{array}$ & $77 \pm 27.74 b$ & $52 \pm 19.23 b$ & $17 \pm 9.08 \mathrm{a}$ & $10 \pm 5.00 \mathrm{a}$ & $7 \pm 4.47 a$ & $2 \pm 2.73 a$ & $0.000 * * *$ \\
\hline & $\begin{array}{c}\text { Means time of } \\
\text { germination } \\
\text { (Days) }\end{array}$ & $7.39 \pm 1.10 \mathrm{bc}$ & $7.84 \pm 0.87 b c$ & $9.39 \pm 2.66 c$ & $9.93 \pm 2.4 \mathrm{lc}$ & $4.40 \pm 3.92 \mathrm{ab}$ & $2 \pm 2.82 a$ & $0.000 * * *$ \\
\hline & Velocity index & $13.78 \pm 2.23 a$ & $12.98 \pm 1.46 \mathrm{a}$ & $11.38 \pm 3.28 \mathrm{a}$ & $10.48 \pm 2.16 a$ & $18.87 \pm 14.68 a$ & $8.33 \pm 11.78 a$ & 0.420 \\
\hline
\end{tabular}

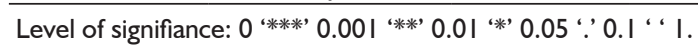

any significant difference between 6,9 , and $12 \mathrm{~g} \cdot \mathrm{L}^{-1} \mathrm{NaCl}$ treatments for Eucalyptus gomphocephala and Eucalyptus microtheca. Moreover, only the $15 \mathrm{~g} \cdot \mathrm{L}^{-1} \mathrm{NaCl}$ level of salinity was considered as the worst treatment and significantly different from the others for Eucalyptus torquata, Eucalyptus gillii and Eucalyptus sargenti. Means time of germination were around 0.77 and 18.26 days for salinity below or equal to $6 \mathrm{~g} \cdot \mathrm{L}^{-1} \mathrm{NaCl}$, and velocity index was maintained elevated even under high $\mathrm{NaCl}$ concentrations, showing the velocity of germination (Table 3). The correlation matrix between the morphological traits of the seeds of the five species of Eucalyptus studied and the germination characteristics of the seeds (GR, MTG and VC) are shown in Figure 4. Concentration of salt and germination rate of seeds were negatively correlated $(\mathrm{P}<0.00 \mathrm{I}$; Pearson coefficient $=$ $-0.839)$, as well as length and width of seeds were positively correlated $(\mathrm{P}<0.00 \mathrm{I}$; Pearson coefficient $=0.582)$ also, width and area of seeds were positively correlated $(\mathrm{P}<$ 0.001 ; Pearson coefficient $=0.822$ ), also length and area of seeds were positively correlated $(P<0.001$;
Pearson coefficient $=0.827)$. Velocity index and osmotic potential were negatively correlated $(P<0.001$; Pearson coefficient $=-0.509)$. The morphological traits of seeds have no effect on the germination rate, average germination time or the velocity coefficient (Figure 4). The interactions between germination parameters and morphological traits of seeds under stress conditions were studied by multivariate analysis, PCA. Regarding the PCA performed for $\mathrm{NaCl}$ treatments, by considering 6 parameters, the first two components (FI and F2) explained $97,89 \%$ of the total variation. The first component (axis I) explained 66,59\% of the variation, followed by 31,30 \% for the second component (axis 2) (Figure 5). The effect of salt stress on the germination of Eucalyptus seeds showed 3 groups (Figure 5): group I formed by E.gompho-cornutaaffected by salt but remains the least sensitive compared to other Eucalyptus species, group 2 consists of $E$. torquata andgroup 3 contains $E$. microtheca, E.gillii and $E$. sargenti. These results were confirmed by modeling analysis. The results from non linear regression were obtained using germination rate as the independent variable and $\mathrm{NaCl}$. This was 
correlated $(\mathrm{P}<0.00 \mathrm{I}$; Pearson coefficient $=0.822 ;)$, also length and area of seeds were positively correlated $(P<0.00$ I; Pearson coefficient $=0.886)$. Velocity index and average time of germination were negatively correlated $(P<0.00$ I; Pearson coefficient $=-0.752)$. The morphological

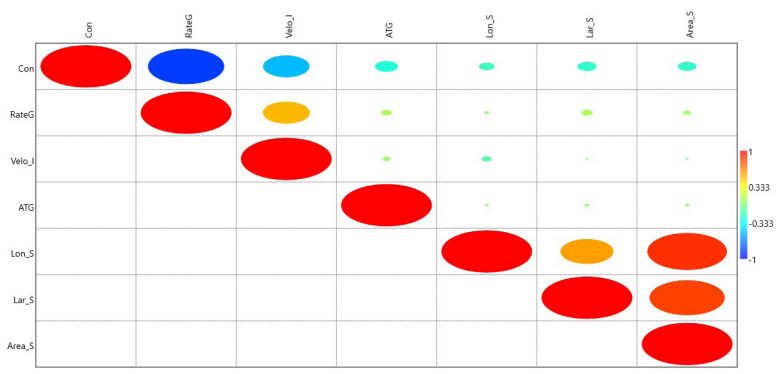

FIGURE 4 Matrice of correlation of seeds morphological traits and germination parameters of 5 Eucalyptus species under salt stress (Con : concentration of salt stress ; RateG : germination rate ; Velo_I : velocity coefficient ; ATG ; mean time of germination; Lä S : widh of seeds; Are S : area of seeds; Lon_S: lenght of seeds).
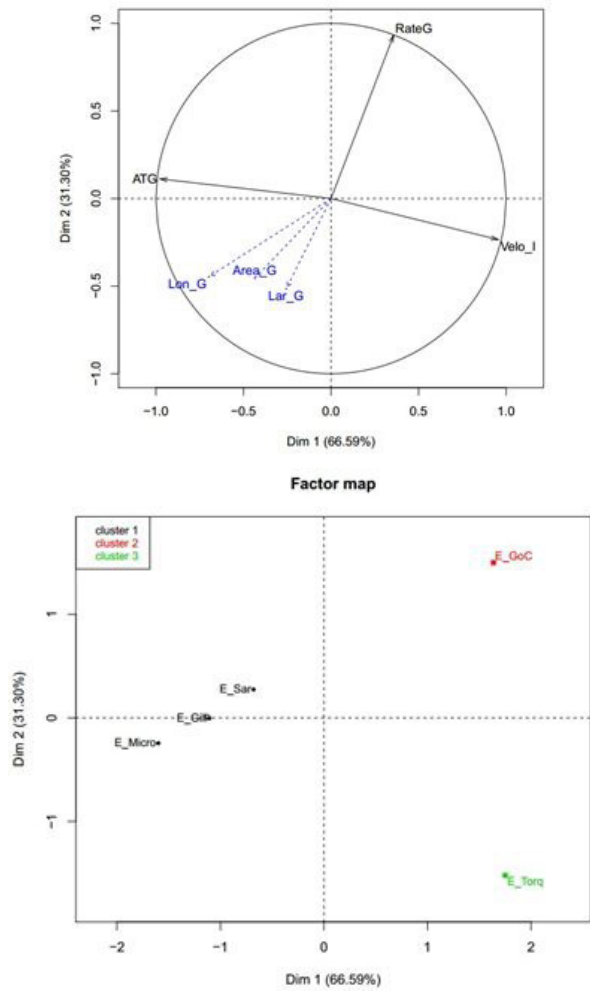

FIGURE 5 Principal component analysis, circle of correlation of seeds morphological traits and germination parameters under salt stress of 05 Eucalyptus species in the factorial plane FI $\times$ F2 (morphological traits of seed : Long_G; lengh of seed, Larg_G; widh of seed, Area_G; area of seed, germination parameters: ATG; means time of germination, RateG; germination rate, Velo_l; velocity index, Eucalyptus species :E_Micro; Eucalyptus microtheca, E_Gilli ; Eucalyptus gillii, E_Sar : Eucalyptus sargenti, E Tor ; Eucalyptus torquata, E GoC : Eucalyptus gomphocephala $x$ Eucalyptus cornuta). done to determine the best non linear combination of the constructs for predicting attitude (Figure 6). The value of the determination coefficient $\left(R^{2}=0.798\right)$, the combination of the variables significantly predicted the dependent variable $(F=290.13 ; P<0.05)$

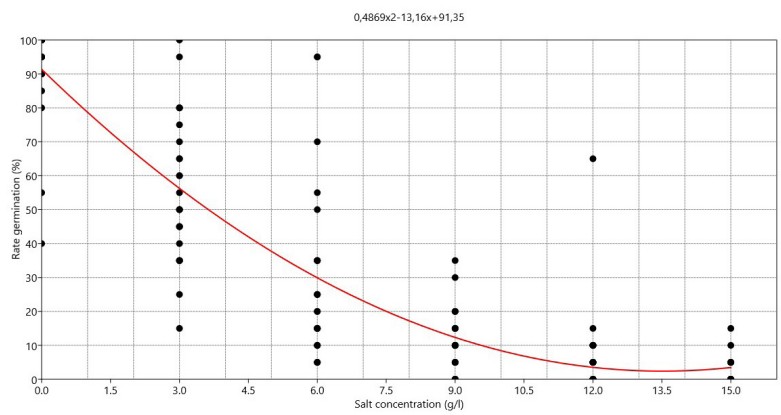

FIGURE 6 Relationship between germination rate of seeds of five Eucalyptus species ans salt concentration.

Effect of osmotic potential on germinationof five species of Eucalyptus

The results of the germination rate of Eucalyptus seeds under different osmotic potentials are shown in Table 4. E. gomphocephala $\times E$. cornuta germination rate was slightly affected by osmotic stress and seeds were able to germinate at up to $-\mathrm{I}$ and $-\mathrm{I} .6 \mathrm{MPa}$ at the rates of $72 \%$ and $61 \%$, respectively. This indicates that the gomphocephala $\times E$. cornuta seeds have high germination capacity even under high osmotic stress. E.gillii, E.microtheca, E.sergenti and E.torquata were significantly affected by stress germination between 9 and $27 \%$ at osmotic stress of $-1.6 \mathrm{MPa}$. The statistical analysis showed that $E$. gomphocephala $\times E$. cornuta had no significant difference between the control and the plants subjected to 0 and $-I \mathrm{MPa}$ treatments, where their germination rate reached $72 \%$. However, although salinity slowly reduced the rate of $E$. gomphocephala $\times E$. cornuta germination, the latter dropped to $61 \%$ when the treatment reached -1.6 $\mathrm{MPa}$. The results of the analysis of variance confirmed that the salinity levels influenced significantly the percentage of germination of E.gillii, E.microtheca, E.sergenti and E. torquata. For 5 species of Eucalyptus, mean time of germination did not reveal any significant difference between 0 to $-1.6 \mathrm{MPa}$. Means time of germination were around 0.56 to 13,98 and velocity index was maintained elevated even under high $\mathrm{NaCl}$ concentrations, showing the velocity of germination (Table I). The correlation matrix between the morphological traits of the seeds of the five species of Eucalyptus studied and the germination characteristics of the seeds (GR, MTG and VC) are shown in Figure 7. Osmotic stress and rate germination of seeds were positively correlated $(\mathrm{P}<0.00 \mathrm{I}$; Pearson coefficient $=0.704$ ), as well length and width of seeds were positively correlated $(\mathrm{P}<0.00 \mathrm{I}$; Pearson coefficient $=$ 0.670 ), also that width and area of seeds were positively 
TABLE 4 Analysis of variance and multiple comparison of means of germination rate, Means time of germination and velocity index of seeds of five Eucalyptus species after transfer from $0,-0.03,-0.1,-0.7,-1$, and $-1.6 \mathrm{MPa} \mathrm{NaCl}$ at $25^{\circ} \mathrm{C}$. Data are means $\pm \mathrm{SD}$. Different letters indicate signifiant diffrences between treatments (osmotic potentiel $\mathrm{MPa}$ ) at $\mathrm{P}<0.05$ according to the Tukey test.

\begin{tabular}{|c|c|c|c|c|c|c|c|c|}
\hline Species & Parameters & $0 \mathrm{MPa}$ & $-0.03 \mathrm{MPa}$ & $-0.1 \mathrm{MPa}$ & $-0.7 \mathrm{MPa}$ & $-I \mathrm{MPa}$ & $-1.6 \mathrm{MPa}$ & $\operatorname{Pr}(>\mathrm{F})$ \\
\hline \multirow{3}{*}{$\begin{array}{c}\text { Eucalyptus } \\
\text { Torquata }\end{array}$} & $\begin{array}{c}\text { Germination rate } \\
(\%)\end{array}$ & $90 \pm 10.00 c$ & $96 \pm 4.18 c$ & $72 \pm 21.67 \mathrm{bc}$ & $57 \pm 12.54 b$ & $19 \pm 14.74 a$ & $9 \pm 4.18 a$ & 0.000 ***** \\
\hline & $\begin{array}{l}\text { Means time of } \\
\text { germination } \\
\text { (Days) }\end{array}$ & $6.58 \pm 1.60 \mathrm{a}$ & $7.81 \pm 1.21 \mathrm{la}$ & $7.91 \pm 1.63 a$ & $5.59 \pm 1.1 \mathrm{la}$ & $|3.70 \pm| \mid .27 a$ & $8.53 \pm 8.8 \mathrm{Ia}$ & 0.374 \\
\hline & Velocity index & $16.03 \pm 4.39 a$ & $13.09 \pm 2.4 \mathrm{la}$ & $13.06 \pm 2.62 \mathrm{a}$ & $18.43 \pm 3.64 a$ & $12.77 \pm 8.63 \mathrm{a}$ & $20.16 \pm 11.70 a$ & 0.356 \\
\hline \multirow{3}{*}{$\begin{array}{l}\text { Eucalyptus } \\
\text { Sergenti }\end{array}$} & $\begin{array}{c}\text { Germination rate } \\
(\%)\end{array}$ & $84 \pm 17.10 \mathrm{~b}$ & $9 \mathrm{I} \pm 5.47 \mathrm{~b}$ & $78 \pm I 5.24 b$ & $60 \pm 11.72 \mathrm{ab}$ & $59 \pm 39.27 \mathrm{ab}$ & $27 \pm 27.52 a$ & $0.000 * * *$ \\
\hline & $\begin{array}{c}\text { Means time of } \\
\text { germination } \\
\text { (Days) }\end{array}$ & $5.66 \pm 0.95 a$ & $5.10 \pm 1.41 \mathrm{a}$ & $5.40 \pm 1.01 \mathrm{a}$ & $5.74 \pm 1.33 \mathrm{a}$ & $4.74 \pm 1.49 a$ & $10.15 \pm 9.97 a$ & 0.370 \\
\hline & Velocity index & $18.04 \pm 2.83 a$ & $20.8 \mathrm{I} \pm 5.75 \mathrm{a}$ & $19.01 \pm 3.29 a$ & $19.21 \pm 4.94 a$ & $22.86 \pm 7.3 \mathrm{la}$ & $19.01 \pm 15.10 \mathrm{a}$ & 0.934 \\
\hline \multirow{3}{*}{ Eucalyptu Gillii } & $\begin{array}{c}\text { Germination rate } \\
(\%)\end{array}$ & $85 \pm 22.63 c$ & $87 \pm 13.50 c$ & $73 \pm 16.04 b c$ & $32 \pm 21.96 a$ & $45 \pm 15.8 \mathrm{Iab}$ & $24 \pm 23.82 a$ & 0.000 **** \\
\hline & $\begin{array}{l}\text { Means time of } \\
\text { germination } \\
\text { (Days) }\end{array}$ & $9.83 \pm 1.56 \mathrm{a}$ & $7.34 \pm 0.85 a$ & $7.50 \pm 1.74 a$ & $7.26 \pm 1.83 a$ & $6.76 \pm 1.53 a$ & $13.98 \pm 8.74 a$ & 0.051 \\
\hline & Velocity index & $10.39 \pm 1.73 a$ & $13.76 \pm 1.59 \mathrm{a}$ & $13.85 \pm 2.92 \mathrm{a}$ & $14.43 \pm 3.28 \mathrm{a}$ & $15.18 \pm 2.47 a$ & $10.23 \pm 6.47 a$ & 0.140 \\
\hline \multirow{3}{*}{$\begin{array}{c}\text { Eucalyptus } \\
\text { Gompho- } \\
\text { cornuta }\end{array}$} & $\begin{array}{c}\text { Germination rate } \\
(\%)\end{array}$ & $88 \pm 11.51 \mathrm{a}$ & $92 \pm 11.51 \mathrm{a}$ & $82 \pm 14.40 \mathrm{a}$ & $78 \pm 24.13 a$ & $72 \pm 27.74 a$ & $6 I \pm 28.56 a$ & 0.238 \\
\hline & $\begin{array}{c}\text { Means time of } \\
\text { germination } \\
\text { (Days) }\end{array}$ & $20 \pm 3.06 a$ & $|7.84 \pm 2.9| \mathrm{a}$ & $16.91 \pm 3.19 \mathrm{a}$ & $16.44 \pm 3.67 \mathrm{a}$ & $18.03 \pm 4.23 a$ & $17.10 \pm 4.00 \mathrm{a}$ & 0.674 \\
\hline & Velocity index & $8.58 \pm 2.27 a$ & $10.67 \pm 1.78 a$ & $11.87 \pm 1.29 a$ & $10.23 \pm 2.34 a$ & $14.29 \pm 1.98 a$ & $\mathrm{II} .69 \pm 4.4 \mathrm{Ia}$ & 0.618 \\
\hline \multirow{3}{*}{$\begin{array}{l}\text { Eucalyptus } \\
\text { Microtheca }\end{array}$} & $\begin{array}{c}\text { Germination rate } \\
(\%)\end{array}$ & $77 \pm 16.04 c$ & $67 \pm 15.24 c$ & $59 \pm 14.74 b c$ & $37 \pm 4.47 b$ & $35 \pm 16.20 b$ & $9 \pm 4.18 \mathrm{a}$ & 0.000 **** \\
\hline & $\begin{array}{c}\text { Means time of } \\
\text { germination } \\
\text { (Days) }\end{array}$ & $6.47 \pm 1.45 a$ & $7.96 \pm 1.42 \mathrm{a}$ & $8.46 \pm 2.20 \mathrm{a}$ & $5.95 \pm 0.98 a$ & $7.40 \pm 0.56 a$ & $5.33 \pm 2.29 a$ & $0.037 *$ \\
\hline & Velocity index & $16.19 \pm 4.21 \mathrm{ab}$ & $12.90 \pm 2.45 \mathrm{ab}$ & $12.48 \pm 3.25 \mathrm{a}$ & $17.24 \pm 3.32 \mathrm{ab}$ & $13.57 \pm 1.02 \mathrm{ab}$ & $21.83 \pm 9.18 b$ & $0.035 *$ \\
\hline
\end{tabular}

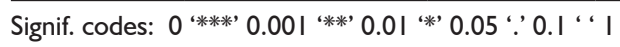

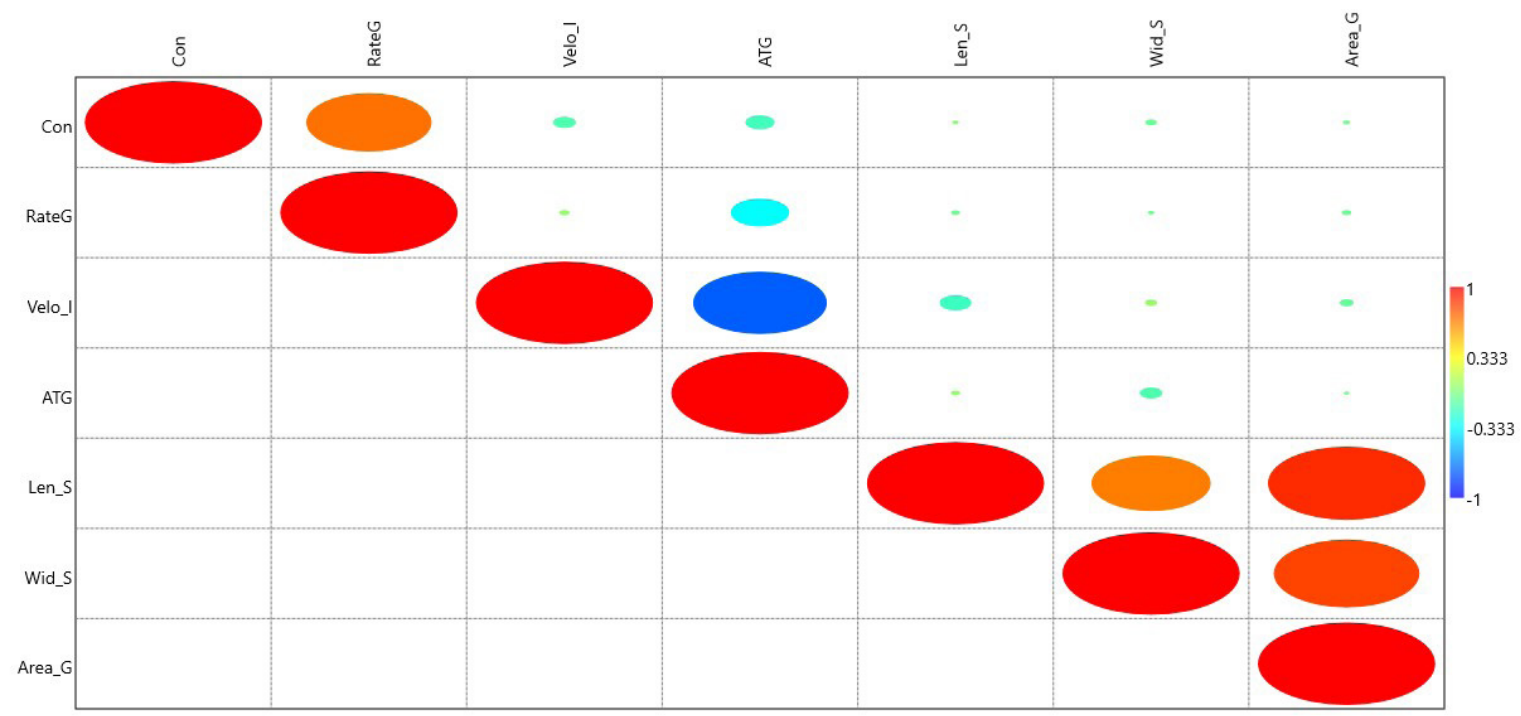

FIGURE 7 Matrice of correlation of seeds morphological traits and germination parameters of 05 Eucalyptus species under osmotic stress (Con: concentration of osmotic stress; RateG: germination rate; Velo_l: velocity coefficient; ATG; mean time of germination; Wid_S: widh of seeds; Are_G: area of seeds; Len_S: lenght of seeds). 
traits of seeds had no effect on the germination rate, average germination time or the velocity coefficient (Figure 7). The interactions between germination parameters and morphological traits of seeds under osmotic potentials were investigated by multivariate analysis, PCA. Considering 6 parameters, the first two components (FI and F2) explained $95,69 \%$ of the total variation. The first component (axis I) explained $78,16 \%$ of the variation, followed by $17,53 \%$ for the second component (axis 2) (Figure 7). The effect of osmotic potential on the germination of Eucalyptus seeds showed 4 groups (Figure 8): group I formed by E.gomphocephala $\times$ E.cornuta, group 2 consists of $E$. Sargenti, group 3 contains E.microtheca and group 4 contains $E$. gillii and $E$. Torquata. Group I composed by E.gomphocephala $x$ $E$. cornuta is not affected by osmotic potential and remains the least sensitive compared to other Eucalyptus species, group 4 is most sensitive to osmotic potential. These results were confirmed by modeling analysis. The results from multiple linear regression were obtained using germination rate as the independent variable and osmotic stress. This was done to determine the best non linear combination of the constructs for predicting attitude (Figure 9). The value of the determination coefficient $\left(R^{2}=0.500\right)$, the combination of the variables significantly predicts the dependent variable $(F=73.745 ; P<0.05)$.

\section{DISCUSSION}

Micromorphological observation of seed coat of nineteen Eucalyptus species

The first phylogenic study of Myrtaceae was carried out by Johnson and Briggs (1984) using inflorescence. Similarly, Wilson et al. (2005) explored the taxonomy and morphology of Myrtaceae using molecular data. External morphology is the basis for classification of many plants such as fruits, flowers, buds, etc (Luqman et al., 2018). Thus, the portrayal of morphological characters for the progression of scientific classification of Myrtaceae is essential for the scientific categorization (Barroso \& Peron, 1994). The present study describes the macromorphological features such as, size, surface of the seeds for nineteen species of Eucalyptus in Tunisia. Seed dimensions (length, width, area) of at least 20 seeds of nineteen species of a sample were measured using a stero microscope (leica DM 205-C). Our analyses
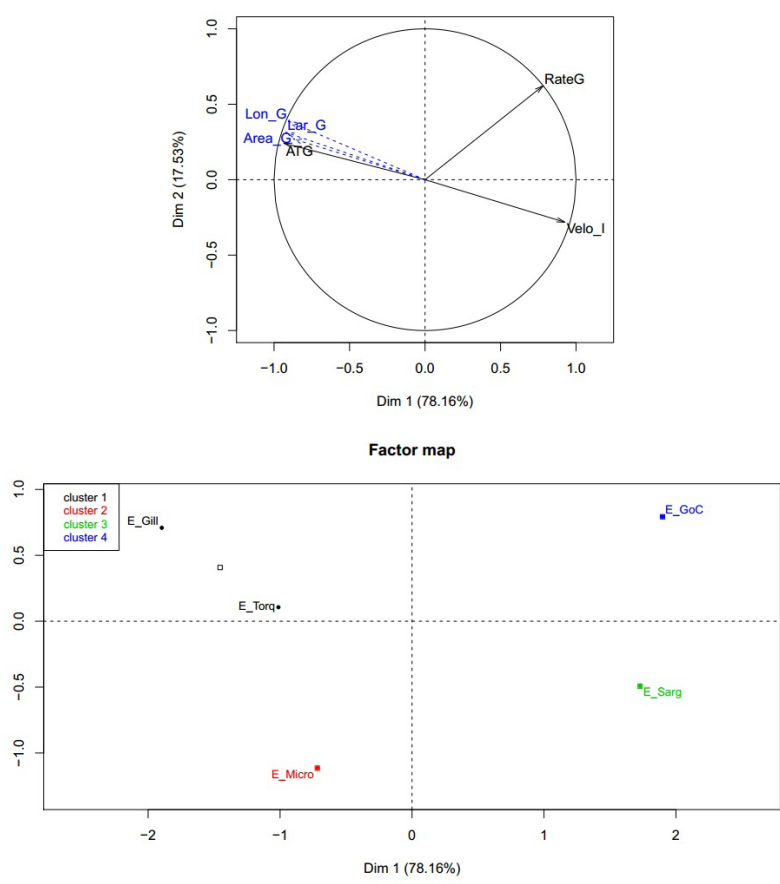

FIGURE 8 Principal component analysis, circle of correlation of seeds morphological traits and germination parameters under osmotic stress of 05 Eucalyptus species in the factorial plane FI $\times$ F2 (morphological traits of seed : Long_G ; lengh of seed, Larg_G; widh of seed, Area_G; area of seed, germination parameters: ATG; means time of germination, RateG; germination rate, Velo I; velocity index, Eucalyptus species: E Micro; Eucalyptus microtheca, E_Gilli; Eucalyptus gillii, E_Sar: Eucalyptus sargenti, E Tor ; Eucalyptus torquata, E_GoC: Eucalyptus gomphocephala $\times$ Eucalyptus cornuta).

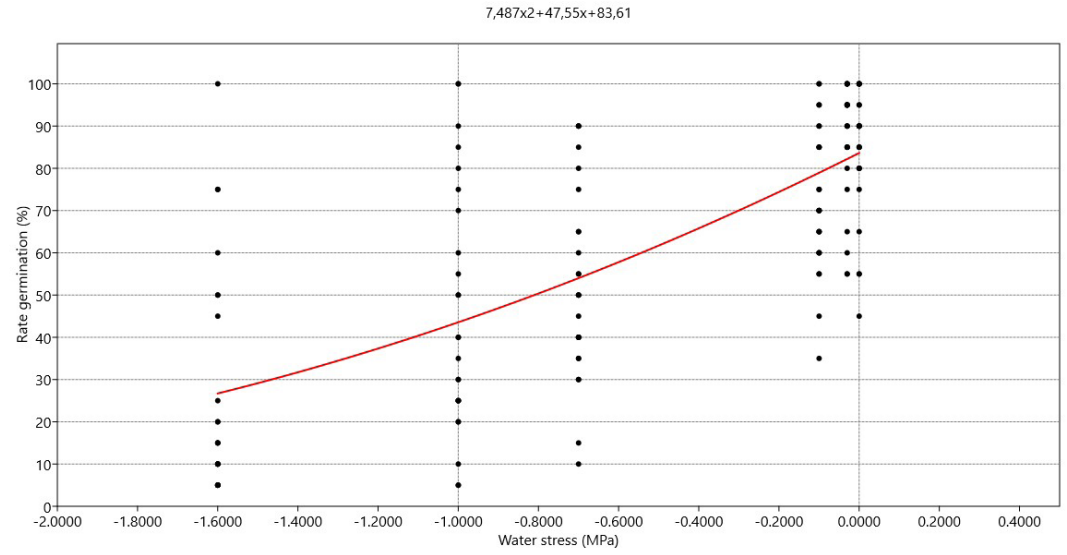

FIGURE 9 Relationship between germination rate of seeds of five Eucalyptus species and osmotic stress. 
of seeds morphology revealed that the observations showed a high diversity of morphological characters in seeds. Micromorphological characters along with seed shape and size are diagnostically important characters to separate species (Luqman et al., 2018). This study clearly illustrated the variability among species in seed size. Seed length ranged from 1.35 to $2.70 \mathrm{~mm}$. Three groups were distinguished: (I) range between $\mathrm{I} .35$ and $1.88 \mathrm{~mm}$, (II) varying between 1.92 and $2.02 \mathrm{~mm}$, and (III) size from 2.22 to $2.70 \mathrm{~mm}$ (Table 2 and Figure 2). E. dumosan, E. diversifolia, E. torquata, E. pimpiniana, $E$. burracoppinensis, $E$, angulosa with larger seed length among the nine species belonged to Group III (2.22-2.70 $\mathrm{mm}) ;$ E. Gillii, E. lehmannii, E. perriniana and E. viminalis came under Group II (1.90-2.02 mm); and the rest of the species belonged to Group I (I.35-I.88 mm). The measurements on seed width and area revealed that they can be classified into three classes (Table 2 and figure 2). The seed coat morphological features had had many morphological variations according the species (Newell \& Hymowitz, 1978). Our results are similar to other studies on the micromorphological observation of seed coat of nine Eucalyptus species, which found that Eucalyptus showed a relatively diverse morphological characters as seed length, width, and weight and the variability among species in seed size (Seed length ranges from I.2I to $2.39 \mathrm{~mm}$ ) (Luqman et al., 2018). Luqman et al. (2018) have also pointed out that three groups of Eucalyptus seed: (I) ranged between I.20 and $1.60 \mathrm{~mm}$, (II) varying between 1.60 and $2.00 \mathrm{~mm}$, and (III) size from 2.00 to $2.40 \mathrm{~mm}$. Eucalyptus pruinosa with larger seed length among the nine species is placed in Group III (2.00-2.40 $\mathrm{mm}$ ); Eucalyptus melanophloia, Eucalyptus microtheca, and Eucalyptus tereticornis come under Group II (I.60$2.00 \mathrm{~mm}$ ); and rest of the species (Eucalyptus Amplifolia, Eucalyptus camaldulensis, Eucalyptus globulus, Eucalyptus kitsoniana and Eucalyptus pellita) belong to Group I (I.20-I.60 mm). Luqman et al. (2018) observed that the measurements on seed width revealed that they can be classified into three classes, with Eucalyptus microtheca belonging to a class ranging from 1.50 to $2.00 \mathrm{~mm}$, Eucalyptus pruinosa to a class varying between 1.00 and $1.50 \mathrm{~mm}$, and the remaining species are placed between 0.50 and $1.00 \mathrm{~mm}$ width class. To study the relationship at generic and infra-generic level, Whiffin and Tomb (1972) studied the importance of seed characteristic features at length and found a relationship among certain angiosperm groups, particularly Melastomataceae. According to Chuang and Heckard (1972), seed surface pattern had high significance in the taxonomic delimitation of certain species of Cordylanthus at subsectional and sectional level. This study has depicted that numerous morphological features in seed can be used as additional supporting features for the identification of taxa. Seed surface characters are different and vary from one another. These variations are observed in the surface, width and lenght.

Effect of salt stress and osmotic potential on germination of 5 species of Eucalyptus

The utilization of Eucalyptus species as a salttolerant industrial crop could be useful to recover salinized land and to valorize its fiber components for numerous industrial applications (paper and pulp, fabrics, textiles, biocomposites, insulation mats, absorption materials, animal bedding, etc.). Eucalyptus represents an alternative crop that may be a feasible source of economically viableand ecologically friendly cellulose. Seed germination is known to be a critical point in seedling establishment, subsequent plant vigor, and ultimately the obtaining of successful crop production. Furthermore, the phenotypic response of seeds to salinity could also be an indicator of plant behavior for the later stages of development (Ayadi et al., 2018). Therefore, our study was conducted as a first attempt in Tunisia to assess the germination behavior of these five species under salt and osmotic stress in order to plan its introduction in forest and urban forest cultivation. Thereafter, multivariate analyses and modeling germination were used to evaluate the salt and osmotic tolerance of Eucalyptus. These statistical methods have numerous advantages. PCA allowed a simultaneous analysis of several parameters to elevate the accuracy of the plant status at diffrent salt levels. Moreover, modeling is an excellent tool to predict whether a model shows interactions between parameters. It appeared that the five Eucalyptus species were not able to germinate at up to 12 and $15 \mathrm{gL}^{-1} \mathrm{NaCl}$ (4 to $15 \%$ ). Similar results obtained by José et al. (2016) who showed that under salt stress, germination continuously decreased, reaching $39 \%$ and I $3 \%$ at $-\mathrm{I} .0 \mathrm{MPa}$ for E. urophylla and E. urophylla $x E$. grandis, respectively. Seed germination and germination speed index decreased as the water potential of the germination medium decreased (José et al., 2016). However, E. urophylla was more tolerant to salt stress; it showed a higher germination percentage under all tested potentials, when compared to the $E$. urophylla $\times E$. grandis. José et al. (20I6) noted that salt stress reduced the germination percentage and speed of $E$. urophylla $\times E$. grandis and Eucalyptus urophylla seeds. Our result 
showed that a low germination rate $(0 \%)$ was detected on Eucalyptus gillii in $15 \mathrm{~g} \cdot \mathrm{L}^{-1}$. This was not in agreement with the findings of Lopes da Silva et al. (2012) who found that Eucalyptus saligna presented higher growth and larger tolerance to the salinity. The largest tolerance of salinity of the Eucalyptus saligna can be due to the larger produced amount of sugar soluble and proline (Lopes da Silva et al., 20I2). The osmotic conditioning in PEG enabled an increase in the final germination speed and percentage under salt stress for both species (José et al., 2016). The five Eucalyptus species were able to germinate at up to $-\mathrm{I} \mathrm{MPa}$ ( 19 to $72 \%)$ with a notable rate of Eucalyptus gomphocephala x Eucalyptus cornuta $(6 / \%)$ at $-\mathrm{I} .6 \mathrm{MPa} \mathrm{NaCl}$. For the hybrid, this germination solution potential caused a marked drop in the germination final percentage from $77 \%$ at $-0.5 \mathrm{MPa}$ to $35 \%$ at $-0.75 \mathrm{MPa}$ (José et al., 2016). The germination of $E$. urophylla drastically decreased only when seeds were placed under - I .0 MPa salt stress. In this case, germination was reduced from $90 \%$ at $-0.75 \mathrm{MPa}$ to $39 \%$ at $-1.0 \mathrm{MPa}$ (José et al., 2016). The conditioning potential of $-1.5 \mathrm{MPa}$ was more effective than -1.0 MPa to induce seed tolerance to germination under moderate salt stress (-0.75 MPa). Martins et al., (20I4) who studied E. grandis and $E$. urophylla, verified that the $-0.8 \mathrm{MPa}$ potential already inhibited germination in practically all species, reducing germination to null or close to zero values, both in water and salt stress. Feikema and Baker, 20I I reported that $E$. grandis was only proper for low salinity soils, since it presented high mortality rate and low volume increment along the years, when submitted to high salinity soils. Interspecies genetic variations for salt tolerance have been related for the Eucalyptus genus (Niknam and Mccomb, 2000). The Eucalyptus camaldulensis Dehnh. is highly recommended to combat salinity, because it can tolerate high levels of $\mathrm{NaCl}$-salinity as compared to other tree species (Marcar, 1993; Akilan et al., 1997; Van der Moezel et al., 1988). Salinity up to a level of $160 \mathrm{mM} \mathrm{NaCl}$ did not affect the survival of $E$. camaldulensis; however, it can affect plant growth and dry-matter production negatively (Rawat and Banerjee, 1998; Grieve et al., 1999). Nawaz et al. (2016) showed that survival of the Eucalyptus camaldulensis plants was not affected by high $\mathrm{NaCl}$ salinity or higher levels of $\mathrm{Pb}$ in nutrient solutions. $E$. camaldulensis plants survived the $\mathrm{NaCl}$-salinity stress at $200 \mathrm{mM} \mathrm{NaCl}$. These results were in agreement with previous studies (Marcar, 1993; Rawat and Banerjee, 1998; Van der Moezel et al., 1988; Gomes et al., 20I2; Peng et al., 20I2) who have shown that $E$. camaldulensis tree species can successfully grow on salt- affcted soils as well as Pb-polluted soils. According to Pulavarty et al. (2016) Eucalyptus camaldulensis under $\mathrm{NaCl}$ is affectedsignificant on the morphological features after 2 months exposure. Salt stress has detrimental effect on plant growth and development (Pulavarty et al., 2016). Plant-water relationship in Eucalyptus is specific, because of its high water uptake ranging from 50 to even $90 \mathrm{~L} /$ day/plant and the particular tolerance of several eucalypts to drought (Joshi \& Palanisami, 20 I I). Ouyanga et al., 2016 suggested that the cumulative annual water use by $E$. urophylla in sandy soil is about $3200 \mathrm{~L} /$ tree; the parameters that explain this high water consumption are in order: rootuptake, leaf transpiration and soil evaporation. Joshi \& Palanisami (20II) reported that eucalypt roots can grow even up to 6-9 $\mathrm{m}$ in stress conditions and extractmore water. Indeed, roots of some species can grow to $30 \mathrm{~m}$ in depth and extract the ground water (FAO, 20II). Eucalyptus species are generally characterized by a great ability of water absorption, as well as a great resistance to the dry conditions. This quality is manifested in morphological and physiological parameters, including root development and changes in osmotic potential, stomatal conductance, gas exchange, transpiration rates and photosynthesis (Saadaoui et al., 2017). The use of Eucalyptus for reforestation under reduced water conditions, essentially with climate change impacts, would pose problems related mainly to its water consumption, biodiversity reduction and environment degradation (Zhang, 20I2). The tolerance to the saline stress can be due to the control of the acquisition and for the allocation of sodium inside the plant, or for the osmotic readjustment and other physiologic processes (Cheeseman, 1988). The inhibition of the growth and the plant production is due to the reduction in the osmotic potential caused by the excess of salts and/or to the toxicant effect of the same ones (Silva et al., 2000). Fredj et al. (20/3), when studying field conditioning levels in coriander cultivars $(0,2,4,6$ and 9 g. $\left.L^{-1} \mathrm{NaCl}\right)$ for three duration periods $(12,24$ and 36 hours), found that the higher the duration, the lower the benefits of conditioning and that a conditioning saline solution in the $4 \mathrm{~g} . \mathrm{L}^{-1}$ concentration provided the best germination results, decreasing significantly in higher concentrations. In the Mediterranean basin, salinity is one of the major constraints impeding germination and affecting seedling and plant growth (Gupta and Huang, 2014). Salt concentration is the most important factor in regulating the germination of non-dormant seeds at the beginning of the growth season. Abiotic stress, depending on its intensity, may severely limit the growth and development of plants (Harfouche et al., 20I4). Salinity and water deficit are the main factors affecting the 
productivity of cultures around the world, especially in arid and semi-arid regions (Jisha et al., 2013; Gholami et al., 2015). $\mathrm{NaCl}$ reduces the efficiency of use of the nutrients, although its translocation is not affected (Silva et al., 2000; Rego et al., 20II). Several morphological characteristics and growth comparison studies of Eucalyptus camaldulensis and E. citriodora are affected by drought stress and the Eucalyptus height gradually decreased as the irrigation interval increased and root length varied drastically against the influence of the drought (Yousaf et al., 2018). The present study aimed tomodeling seed germination in response to salt and water. R-square $\left(r^{2}\right)$ values of regression coefficients established for five Eucalyptus varied from 0.798 (salt concentration) to 0.500 (osmotic potential).

\section{CONCLUSION}

In conclusion, the hybrid $E$. gomphocephala $\times E$. cornuta was more tolerant to salt stress ( $15 \%$ at $\left.12 \mathrm{~g} \mathrm{~L}^{-1}\right)$ and osmotic potential $(61 \%$ at $-1.6 \mathrm{MPa})$ than the others species of Eucalyptus; it showed a higher germination percentage under all tested potentials, when compared to the not hybrid species of Eucalyptus. Seeds morphology revealed that the observations shown diversity of morphological characters in seeds. Area, length and width of seeds vary significantly between species of Eucalyptus. Micromorphological characters can provide basis for classification and delimitation of genus Eucalyptus. Our results suggest that extensive work is needed to be carried out on the seed micromorphology of genus Eucalyptus considering more species. These characters can play an important role in a delimitation and accurate identification of complex or closely related species.

\section{REFERENCES}

AFFONSO, C.E.; DA SILVA, G.Z.; JEROMINI, T.S.; MARTINS, C.C. Germination test of Eucalyptus phaeotricha seeds. Revista Brasileira de Engenharia Agrícola e Ambiental. v.22, n.9, p.653-657. 2018.

ASHRAF, M.; HARRIS, P. J. C. Potential biochemical indicators of salinity tolerance in plants. Plant Sciences. v. I66, p.3-16, 2004.

BARROSO, G. ; PERON, M. Myrtaceae. LIMA MPM, GUEDES BRUNI RR, orgs. Reserva Ecologica de Macae de Cima: Nova Friburgo-RJ. Aspectos floristicos das especies vasculares (Vol. I, pp. 26I-302). Jardim Botânico do Rio de Janeiro, 1994.

BATISH, D.R. ; SINGH, H.P. ; KOHLI, R.K. ; KAUR, SH. Eucalyptus essential oil as a natural pesticide. Forest Ecology and Management. v.256, n. I2, 2166-2174, 2008.

BEWLEY, J.D. ; BLACK, M. Seeds: Physiology of Development and Germination. 2nd ed. New York, NY, USA: Plenum Press. 1994.
BOUKEF, M.K. Médicine traditionnelle et pharmacopée, les plantes dans la médicine traditionnelle tunisienne. Agence de Coopération Culturelle et Technique. ISBN 929028- p.85-89, 1986.

CERMELLI, C. ; FABIO, A. ; FABIO, G. ; QUAGLIO, P. Effect of Eucalyptus essential oil on respiratory bacteria and viruses. Current Microbiology. v.56, p.89-92. 2008.

CHAUM, S. ; SOMSUEB, S. ; SAMPHUMPHUANG, T. ; KIRDMANEE, C. Salt tolerant screening in eucalypt genotypes (Eucalyptus spp.) using photosynthetic abilities, proline accumulation, and growth characteristics as effective indices. In Vitro Cell Develeppment Biology. v.49, p.61I-619, 2013.

CHEESEMAN, J. M. Mechanisms of salinity tolerance in plants. Plant Physiology. v.87, p.547-550, 1998.

CHENG, J. P. et al. Dynamic quantitative trait locus analysis of seed dormancy at three development stages in rice. Molecular Breeding. v.34, p.50I-510,2014.

CHUANG, T.I.; HECKARD, L.R. Seed coat morphology in Cordylanthus (Scrophulariaceae) and its taxonomic significance. American Journal of Botany. v.59, p. 258-265, 1972.

COSSALTER, C., PYE-SMITH, C. Fast-Wood Forestry: Myths and Realities. Center for International Forestry Research, Indonesia. 2003.

DU, H.; ZENG, F; PENG, W.; WANG, K.; ZHANG, H.; LIU, L.; SONG, T. Carbon Storage in a Eucalyptus Plantation Chronosequence in Southern China. Forests. v.6, p. I763I778, 2015.

ELAISSI, A.; MEDINI, H.; ROUIS, Z.; KHOUJA, M.L.; CHEMLI, R.; HARZALLAH-SKHIRI, F. Impact of geographic's variation on the essential oil yield and chemical composition of three Eucalyptus species acclimated in tunisia. Journal of Experimental Biology and Agricultural Sciences. v.3, n.3, p.325-336, 2015.

ELAISSI, A. ; ROUIS, Z. ; ABID BEN SALEM, N. ; MABROUK, S. ; BEN SALEM, Y. ; BEL HAJ SALAH, K. ; AOUNI, M. ; FARHAT, F. ; CHEMLI, R. ; HARZALLAH, S. ; KHIRI, F. ; KHOUJA, M.L. Chemical composition of 8 Eucalyptus species' essential oils and the evaluation of their antibacterial, antifungal and antiviral activities. BMC Complementary and Alternative Medicine. 12:81. 2012.

ELLIS, R.H. ; ROBERTS, E.H.. The quantification of ageing and survival in orthodox seeds. Seed Science Technologie. v.9, p.373-409, 198I.

ENCE. Sustainable Forest Management and Eucalyptus, Grupo Empresarial ENCE, Spain. 76 pp

MYBURG, A., GRATTAPAGLIA, D., TUSKAN, G., HELLSTEN, U., HAYES, R., GRIMWOOD, J., et al. 20I4. The genome of Eucalyptus grandis. Nature. v.509, p.356-362, 2009. 
FAO. Eucalyptus in East Africa, Socio-economic and environmental issues, by Gessesse Dessie, Teklu Erkossa. Planted Forests and Trees Working Paper 46/E, Forest Management Team, Forest Management Division. FAO, Rome. 30 pp, $201 \mathrm{I}$.

FEIKEMA, P.M. ; SASSE, J.M. ; BANDARA, G.D. Chloride content and biomass partitioning in Eucalyptus hybrids grown on saline sites. New Forest. 43:89-107, 2012.

FEIKEMA, P. M.; BAKER, T.G. Effect of soil salinity on growth of irrigated plantation Eucalyptus in south-eastern Australia. Agricultural Water Management. v.98, n.7, p.II80II88, 20II.

FLADUNG, M.; SCHROEDER, H.; WEHENKEL, C.; KERSTEN, B. Differentiation of six Eucalyptus trees grown in Mexico by ITS and six chloroplast barcoding markers. Silvae Genetica. v.64, n.3, p.121-130, 2015.

FLORSHEIM, S.M.B. ; COUTO, H.T.Z. ; LIMA, I.L. ; LONGUI, E.L. Variação nas dimensões dos elementos anatômicos da madeira de Eucalyptus dunnii aos sete anos de idade. Revista dolnstituto Florestal. v. I, n. I, p.79-9I, 2009.

FREDJ, M.B.; ZHANI, K.; HANNACHI, C.; MEHWACHI, T.. Effect of $\mathrm{NaCl}$ priming on seed germination of four coriander cultivars (Coriandrum sativum). EurAsian Journal of BioSciences, v.7, p.2I-29, 2013.

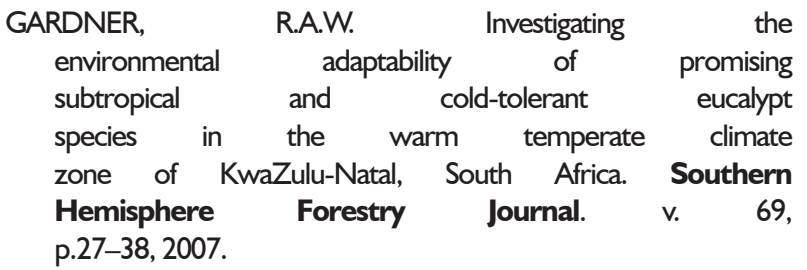

GHOLAMI, M.; MOKHTARIAN, F; BANINASAB, B. Seed halopriming improves the germination performance of black seed (Nigella sativa) under salinity stress conditions. Journal of Crop Science and Biotechnology. v. I8, n. I, p.2I-26, 2015.

GILLES, M.; ZHAO, J.; AN, M.; AGBOOLA, S. Chemical composition and antimicrobial properties of essential oils of three Australian Eucalyptus species. Food Chemistry. v. II9, p.73I-737, 2010.

GOMES, M.; MARQUES, T.; CARNEIRO, M.; SOARES, A.M. Anatomical characteristics and nutrient uptake and distribution associated with the Cd-phytoremediation capacity of Eucalyptus camaldulenses Dehnh. Journal Soil and Science Plant Nutrition. v. I2, p.48I-496, 2012.

GUPTA, B. ; HUANG, B. Mechanism of salinity tolerance in plants: physiological, biochemical, and molecular characterization. International Journal of Genomics. 2014.

HACHICHA, M. Les sols salés et leur mise en valeur en Tunisie. Sécheresse 18: 45-50 (in French). 2007.
HARFOUCHE, A.; MEILAN, R.; ALTMAN, A. Molecular and physiological responses to abiotic stress in forest trees and their relevance to tree improvement. Tree Physiology. v.34, n.II, p.II8I-II98, 2014.

HUANG, Y.Y.; ZHONG, X.Q.; WANG, J.Z.; NI, C.Y.; LI, Q.X. The eco-economics problems which China should attend in the process development Eucalyptus paper making. Ecological Economy. 08, 38-4I. 2007.

INDUSTRIA BRASILEIRA DE ÁRVORES - IBÁ. Relatório IBÁ 2015:ano base 2014. Brasília: IBÁ; 2015.

INF. INVENTAIRE NATIONAL FORESTIER. Ministère de l'Agriculture et des Ressources Hydrauliques et de la peche. Direction Générale des Forêts. 50 p. 2005.

ISHAG, O.A.O. ; ERWA, I.Y. ; DIRIYE, M.A. ; LAWANE, A.A.M. ; AHMED, H.M. ; AHMED, F.A. ; MERGANI, S.E. ; ELAMIN, A. ; OMER, A.B. 2018. Antimicrobial Potential and Phytochemical Screening of Eucalyptus camaldulensis and Eucalyptus microtheca Leaves Extracts. South Asian Research Journal of Natural Products. I(3): I-6, 20 I8.

JHA, R. ; REGMI, R. ; SIMON, L.S. ; LAL, A.A. Efficacy of Eucalyptus essential oil against leaf spot (Alternaria solani) of Solanum melongena L. ARPN. Journal of Agricultural and Biological Science. 9: 320-322, 2014.

JISHA, K.C.; VIJAYAKUMARI, K.; PUTHUR, J.T. Seed priming for abiotic stress tolerance: an overview. Acta Physiologiae Plantarum. v.35, n.5, p.|38|-|396, 2013.

JOHANSSON, S. ; TUOMELA, K. Growth of 16 provenances of Eucalyptus microtheca in a regularly irrigated plantation in eastern Kenya. Forest Ecology and Management. 82, I I-18. 1996.

JOHNSON, L. ; BRIGGS, B. Myrtales and Myrtaceae.A phylogenetic analysis. Annals of The Missouri Botanical Garden. 7I, 700-756, 1984.

JOSÉ, AC.; SILVA, NCN.; FARIA, JMR.; PEREIRA, WVS. Inflence of priming on Eucalyptus spp seeds' tolerance to salt stress. Journal of Seed Science, v.38, n.4, p.329-334, 2016.

JOSHI, M. ; PALANISAMI, K. Impact of Eucalyptus plantations on ground water availability in South Karnataka. ICID 2 Ist International Congress on Irrigation and Drainage, 255262, 2011 .

KHOUJA, M.L. ; KHALDI, A. ; REJEB, M.N. Results of the Eucalyptus introduction trials in Tunisia, Proceedings of the International Conference Eucalyptus in the Mediterranean basin: perspectives and new utilization, October 15-19, 2000, Centro Promozione Pubblicita ', Florence, p. 163. 200 I.

KOTOWSKI, F. Temperature relations to germination of vegetable seeds. Proceedings of the American Society of Horticultural Science. 23: 176- I77, 1962. 


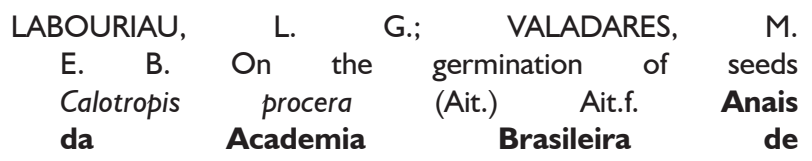
Ciências, v.48, p.263-284, 1976.

LEICACH, S.R. ; YABER G.M.A. ; CHLUDIL, H.D. ; GARAU, A.M. ; GUARNASCHELLI, A.B. ; FERNANDEZ, P.C. Chemical defenses in Eucalyptus species: A sustainable strategy based on antique knowledge to diminish agrochemical dependency, new advances and contributions to forestry research. Oteng-Amoako, A.A. (ed.). New Advances and Contributions to Forestry Research. p.225-256, 2012.

LI, C. Envisage ecological challenges of Eucalyptus plantations. Eucalyptus Science Technology. v.32, n.4, p.46-50, 2015.

LOPES DA SILVA, A.L. ; DE OLIVEIRA, Y. ; DIBAX, R. ; DA LUZ COSTA, J. ; NEWTON SCHEIDT, G. ; PEREIRA MACHADO, M. ; PEREZ GUERRA, E. ; EBLING BRONDANI, G. ; OLIVEIRA ALVES, A. Hydroponics growth of Eucalyptus saligna $\mathrm{Sm}$. on salt-stress mediated by sodium chloride. Journal of Biotechnology and Biodiversity. Vol. 3, N. 4: p.2I3-2I8, 2012.

LOPES, C.S.D. ; NOLASCO, A.M. ; TOMAZELLO M.FO. ; DIAS C.T.S. ; PANSINI, A. Estudo da massa específica básica e da variação dimensional da madeira de três espécies de eucalipto para a indústria moveleira. Ciência Florestal. v.21, n.2, p315- 322, 2011.

LUQMAN,M.;ZAFAR, M.;AHMAD, M.; etal. Micromorphological observation of seed coat of Eucalyptus species (Myrtaceae) using scanning electron microscopy technique. Microscopy of Research Techology. p. I-10, 2018.

MARCAR, N. Waterlogging modifis growth, water use and ion concentrations in seedlings of salt-treated Eucalyptus camaldulensis, E. tereticornis, E. robusta and E. globulus. Australian Journal of Plant Physiology. v.20, p. I- I3, 1993.

MARTINS, C. C.; MARTINELLI-SELENE, A.; NAKAGAWA, J. Estágio de colheita e substrato para o teste de germinação de sementes de ipê (Tabebuia chrysotricha (Mart. ex DC.) Standl.). Revista Árvore, v.32, p.27-32, 2008.

MARTINS, C.C.; PEREIRA, M.R.R.; LOPES, M.T.G. Germinação de sementes de eucalipto sob estresse hídrico e salino. Bioscience Journal. v.30, n.I, p.3।8-329, 2014.

MERCHANT, A. ; CALLISTER, A. ; ARNDT, S. ; TAUSZ, M. ; ADAMS, M. Contrasting physiological responses of six Eucalyptus species to water deficit. Oxford Journal Annals of Botany. v. 100, p. 1507-1515, 2007.

NASIM, M. ; QURESHI, RH. ; AZIZ, T. ; SAQIB, M. ; NAWAZ, S. ; SAHI S.T. ; PERVAIZ, S. Growth and ionic composition of salt-stressed Eucalyptus camaldulensis and Eucalyptus tereticornis. Pakistan Journal of Botany. v.40, p.799-805, 2008.
NAWAZ, M.F; GUL, S.; TANVIR, M.A.; AKHTAR, J.; CHAUDARY, S.; AHMAD, I. Inflence of $\mathrm{NaCl}$-salinity on $\mathrm{Pb}$-uptake behavior and growth of River Red gum tree (Eucalyptus camaldulensis Dehnh.). Turkish Journal of Agriculture and Forestry. v.40, p.425-432., 2016.

NEWELL, C.; HYMOWITZ, T. Seed coat variation in Glycine Willd. subgenus Glycine (Leguminosae) by SEM. Brittonia. v.30, n. I, p.76-88, 1978.

NIKNAM, S.R; MCCOMB, J. Salt tolerance screening of selected Australian woody species - a review. Forest Ecology and Management. v. I39, n. I, p.I-19, 2000.

OMER ADAM, O.; OMER ISHAG, O. A. O.; ERWA, I. Y.; DIRIYE, M.A.; LAWANE, A. A. M.; AHMED, H. M.; AHMED, F.A. ; MERGANI, S.E. ; ELAMINA. ; OMER, A.B. ntimicrobial Potential and Phytochemical Screening of Eucalyptus camaldulensis and Eucalyptus microtheca Leaves Extracts. South Asian Research Journal of Natural Products. v. I, n.3, p. I-6, 2018.

OTIENO, N. E.; ANALO, C. Local indigenous knowledge about some medicinal plants in and around Kakamega forest in western Kenya [version 2; referees: 2 approved]. FI000Res. I : 40, 2012.

OUESLATI, M. Contribution à l'élaboration d'un guide dendrologique dans le nord-Ouest de la Tunisie, Tome I, les feuillus, PFE, ISPT, 30p, 2002.

OUYANGA, Y.; XU, D.; LEININGER, T.D.; ZHANG, N. A system dynamic model to estimate hydrological processes and water use in a eucalypt plantation. Ecological Engineering. v.86, p.290-299, 2016

PENG, X.; YANG, B.; DENG, D.; DONG, J.; CHEN, Z. Lead tolerance and accumulation in three cultivars of Eucalyptus urophylla $X$ Eucalyptus grandis: implication for phytoremediation. Environment Earth Sciences. v.67, p.15I5-1520. 2012.

PEREIRA, V.; DIAS, C.; VASCONCELOS, M.C.; ROSA, E.; SAAVEDRA, M.J. Antibacterial activity and synergistic effects between Eucalyptus globulus leaf residues (essential oils and extracts) and antibiotics against several isolates of respiratory tract infections (Pseudomonas aeruginosa). Industrial Crops and Products. v.52, p. I-7. 2014.

PINO, J.A.; MARBOT, R.; QUERT, R.; GARCIA, H. Study of essential oils of Eucalyptus resinifera Smith, E. tereticornis Smith and Corymbia maculata (Hook.) K. D. Hill \& L. A. S. Johnson, grown in Cuba. Flavour and Fragrance Journal. v. I7, p.I-I4. 2002.

PULAVARTY, A. ; KUKDE, S. ; SHINDE, VM., B., SARANGI, B.K. Morphological, physiological and biochemical adaptations of Eucalyptus citriodora seedlings under $\mathrm{NaCl}$ stress in hydroponic conditions. Acta Physiology Plant. 2016.

QUEIROZ DOS SANTOS, Y.; SILVA CAMPOS CARELLI, G. ; OLIVEIRA DE VERAS, B et al. Antitryptical, anticoagulant and hemagglutinating activities of Eucalyptus sp. Seeds, 2019. 
R Development Core Team R: a language and environment for statistical computing. R Foundation for Statistical Computing, Vienna. 2009.

RAWAT, J.; BANERJEE, S. The inflence of salinity on growth, biomass production and photosynthesis of Eucalyptus camaldulensis Dehnh. and Dalbergia sissoo Roxb. seedlings. Plant Soil. v.205, p.163-169. 1998.

REGO, S. S.; FERREIRA, M. M.; NOGUEIRA, A. C.; GROSSI, F; SOUSA, R. K.; BRONDANI, G. E.; ARAUJO, M. A.; LOPES DA SILVA, A. L. Estresse hídrico e salino na germinação de sementes de Anadenanthera colubrina (Veloso) Brenan. Journal of Biotechnology and Biodiversity. v.2, p.37-42. $201 \mathrm{I}$.

REZENDE, R. N.; LIMA, J. T.; RAMOS E PAULA, L. E.; HEIN, P. R. G.; SILVA, J. R. M. Wood Permeability in Eucalyptus grandis and Eucalyptus dunnii. Floresta e Ambiente. v.25, n. I, p.e20I50228, 2018.

SAADAOUI, E.; BEN YAHIA, K.; DHAHRI, S.; BEN JAMAA, M. L.; KHOUJA, M. L. An overview of adaptative responses to drought stress in Eucalyptus spp. Forestry Studies. v.67, p.86-96. 2017.

SEIGUE,A. La foret circumméditerranéenne et ses problèmes, technique agricoles et production méditerranéennes. Editions GP Maisonneuve et Larose. 1985.

SILVA A. L. L. D.; OLIVEIRA, Y. D.; DIBAX, R.; COSTA, J. D. L.; SCHEIDT, G. N.; MACHADO, M. P.; GUERRA, E. P.; BRONDANI, G. E.; ALVES, S. A. O. Hydroponics growth of Eucalyptus saligna $\mathrm{Sm}$. on salt-stress mediated by sodium chloride. Journal of Bacteria Biotechology. v.3, p.213-218. 2012 .

SILVA, F. A. M.; ROGERIO MELLONI, R.M.; MIRANDA, J.R.P; CARVALHO, J.G. , Efeito do estresse salino sobre a nutrição mineral e o crescimento de mudas de aroeira (Myracrodruon urundeuva) cultivadas em solução nutritiva. Cerne. v.6, p.52-59, 2000.

SINGH, V.; TOKY, O. P. Biomass and net primary productivity in leucaena, acacia and Eucalyptus, short-rotation, highdensity (energy) plantations in arid India. Journal of Arid Environments. v.31, p.301-309, 1995.

SOARES, T. S.; CARVALHO, R. M. M. A.; VALE, A. B. Avaliação econômica de um povoamento de Eucalyptus grandis destinado a multiprodutos. Revista Árvore. v.27, n.5, p.689-694, 2003

SOKAL, R. R.; ROHLF, F. J. Biometry: Th Principles and Practice of Statistics in Biological Research. 3rd ed. New York, NY, USA: W.H. Freeman and Co. 1995.

SOUZA, C. R.; ROSSI, L. M. B.; AZEVEDO, C. P.; LIMA, R. M. B. Comportamento da Acacia mangium e de clones de Eucalyptus grandis $\mathrm{x}$ Eucalyptus urophylla em plantios experimentais na Amazônia Central. Scientia Forestalis. v.65, p.95-101, 2004.
SU, Y. C.; HO, C. L.; WANG, C. L.; WANG, E. I. C.; CHANG, S.T. Antifungal activities and chemical compositions of essential oils from leaves of four Eucalypts. Taiwan Journal of Forest Science. v.2I, p.49-6I, 2006.

TAKAHASHI, T.; KOKUBO, R.; SAKAINO, M. Antimicrobial activities of Eucalyptus leaf extracts and flvonoids from Eucalyptus maculata. Lettre of Application Microbiology. v.39, n. I, p.60-64, 2004.

TAYLOR, A. G.; ALLEN, P. S.; BENNETT, M. A.; BRADFORD, K. J.; BURRIS, J. S.; MISRA, M. K. Seed enhancements. Seed Science Research, v.8, n.2, p.245-256, 1998.

TOMAZ, C. A.; MARTINS, C. C.; SILVA, G. Z. da; VIEIRA, R.D. Period of time taken by Brachiaria humidicola (Rendle) Scheweick seed to complete germination. Revista Semina: Ciências Agrárias, v.37, p.693-700, 2016.

TURNBULL, J.W. Eucalypt plantations. New Forest. v. I7, p.37-52, 1999

VAN DER MOEZEL, P.; WATSON, L.; PEARCE-PINTO, G.; BELL, D. The response of six Eucalyptus species and Casuarina obesa to the combined effct of salinity and waterlogging. Australian Journal ofPlant Physiology. v. I5, p.465-474, 1988.

VECCHIO, M. G.; LOGANES, C.; MINTO, C. Beneficial and healthy properties of Eucalyptus plants: A great potential use. The Open Agriculture Journal. v. 10, p.52-57, 2016.

WANG, L. et al.. Identifcation of QTLs with additive, epistatic and QTL $\times$ development interaction efects for seed dormancy in rice. Planta. v.239, p.4II-420, 2014.

WEN, Y. G. Ecological and social issues and scientific development of Eucalyptus in China. Forestry Press, Beijing. 2009.

WHIFFIN, T.; TOMB, A.S. The systematic significance of seed morphology in the neotropical capsular-fruited Melastomataceae. American Journal of Botany. v.59, p.4I I-422, 1972.

WILSON, P. G.; O'BRIEN, M.; HESLEWOOD, M.; QUINN, C. Relationships within Myrtaceae sensu lato based on a matK phylogeny. Plant Systematics and Evolution. v.25 I, n. I, p.3-19, 2005

WOODWARD, A. J.; BENNETT, I. J. The effect of salt stress and abscisic acid on proline production, chlorophyll content and growth of in vitro propagated shoots of Eucalyptus camaldulensis. Plant Cell Tissus Organe Culture. v.82, p. I89-200, 2005

YANG, X.; LII, D.; MCGROUTHER, K.; LONG, W.; LI, Y.; CHEN, Y.; LV, X.; NIAZI, N.K.; SONG, Z.; WANG, W. Effect of Eucalyptus forests on understory vegetation and soil quality. International symposium on forest soils. Journal of Soils Sediments. 2016. 
YOUSAF, M. S.; FAROOQ, T. H.; AHMAD, I.; GILANI, M. M.; RASHID, M. H.; GAUTAM, N. P.; ISLAM, W.; ASIF, M.; WU, P. Effect of Drought Stress on the Growth and Morphological Traits of Eucalyptus camaldulensis and Eucalyptuscitriodora. PSM Biological Research. v.3, n.3, p.85-9I, 2018.

ZHANG, C.; FU, S. Allelopathic effects of Eucalyptus and the establishment of mixed stands of Eucalyptus and native species. Forest Ecolgy Management. 2009.
ZHANG, W. J. Did Eucalyptus contribute to environment degradation? Implications from a dispute on causes of severe drought in Yunnan and Guizhou, China. Environmental Skeptics and Critics. v. I, n.2, p.34-38, 2012.

ZOHAR, Y.; STEFANO, J. D.; BARTLE, J. Strategy for screening Eucalyptus for saline lands. Agroforestry System. v.78, p. 127-137, 2010. 